\title{
From Feudal Colonization to Agrarian Capitalism in Mallorca: Peasant Endurance Under the Rise and Fall of Large Estates (1229- 1900)
}

\author{
GABRIEL JOVER, IVAN MURRAY, ONOFRE FULLANA AND RICARD SOTO
}

\begin{abstract}
The colonization of Mallorca gave rise to a late-feudal agrarian society that evolved towards capitalism based on large estates owned by noblemen who hired large numbers of wage labourers from among smallholders living in agro-towns, the dispossessed remnants of a formerly wealthier peasantry. These well-off peasants originated from when the colonization frontier was open in the $13^{\text {th }}$ and $14^{\text {th }}$ centuries, but had been defeated when three peasant-plebeian revolts were crushed. Afterwards, Mallorca followed a latifundist transition towards agrarian capitalism similar to southern Italy or Spain, in sharp contrast with the middle-peasant paths seen in Catalonia or Valencia. Land rent rose while agricultural wages fell from 1659 to 1800. Peasant families could not survive, and had to supplement wages with the products of their own plots. This set a socio-agroecological limit to growth in this agrarian class structure. The agrarian crisis at the end of the 19th century bankrupted the Mallorcan nobility. Bankers bought much land and sold it on as small allotments. This expanded the intensive cropping formerly limited to agro-town belts, giving rise to a new 'peasantization'. Despite their subordination, Mallorcan peasants had survived and created complex agroecological landscapes endowed with a rich biocultural heritage.
\end{abstract}

\section{PEASANTS MAKE THEIR OWN HISTORY... EVEN UNDER A LONG- LASTING LATIFUNDIST AGRARIAN CLASS STRUCTURE}

From the 1960s to the end of the 1980s there was an thought-provoking debate between Marxist and Liberal historians on the transition from feudalism to agrarian capitalism focused on the way agrarian class structures led to different paths towards economic

\footnotetext{
Enric Tello and Ricard Soto, Department of Economic History, Institutions, Policy and World Economy, University of Barcelona, Diagonal Avenue 690, 08034 Barcelona, Spain, e-mails: tello@ub.edu, ricardsoto@ub.edu. Gabriel Jover, Economics Department, University of Girona, Montilivi Campus, 17003 Girona, Spain, e-mail: gabriel.jover@udg.edu. Ivan Murray, Department of Geography, University of Balearic Islands, Valldemossa Road km 7.5, 07122 Palma de Mallorca, Spain, e-mail: Ivan.Murray@uib.es. Onofre Fullana, PhD student at the University of Balearic Islands and technical assistant of the Organic Farming Association of Mallorca (APAEMA), e-mail: nofrefullana@yahoo.es.

This work has been funded by the Spanish project HAR2015-69620-C2-1-P, and the international Partnership Grant SSHRC 895-2011-1020 on 'Sustainable farm systems: long-term socio-ecological metabolism in Western agriculture' funded by the Social Sciences and Humanities Research Council of Canada.
} 
1 development or underdevelopment (Moore 1967; Sweezy et al. 1976; Brenner 1976;

2 Kriedte 1983; Aston and Philpin 1985; Duplessis 1997). The 'agrarian question'

3 discussed at length within Marxism (Akram-Lodhi and Kay 2010a, 2010b) was

4 broadened and deepened by this debate, which included contributions from a third

stream of heterodox scholars who vindicated the role of peasants and rejected the idea that their fate had to be the 'dump of history' or the 'backwardness of underdevelopment' (Polanyi 1977, 2001; Wolf 1966, 1982; Shanin 1971, 1972; Scott 1998).

However, after the fall of the Berlin Wall in 1989 many scholars considered it politically incorrect to continue talking about social classes, agrarian class structures and class struggle. Ironically, at a time when income inequality moved into a steep global rise (Atkinson, Piketty and Saez 2011; Milanovic 2011; Stiglitz 2012; Piketty 2014; Galbraith 2012, 2016), very many humanistic historians refused to keep searching for empirical data on people's material lives and resorted to fancy biographical narratives. Conversely, most economic historians moved towards a neoclassical viewpoint whereby social and political institutions only matter when considered 'extractive' and risk disturbing free market functioning (Acemoglu and Robinson 2006). This methodological individualism has concealed social inequality as a research issue throughout the period when it became more important worldwide, and up until the 2007 Great Recession (Brenner 2006; Harvey 2010; Foster and McChesney 2012; Mirowski 2013).

2 Land distribution and social inequality only continued to be studied in some 3 heterodox scholar fringes of: Development Economics and Political Economy (Agarwal 4 1994; Bryceson et al. 2000; Griffin et al. 2002; McMichael 2008; Byres 2009; Kay 2009; Borrás 2010), Rural and Social History (Hilton 1990; Allen 1992; Vanhaute 2008; Van Bavel and Hoyle 2010; Shaw-Taylor 2012), Peasant Economics (Chayanov 7 1966; Georgescu-Roegen 1976; Ellis 1988, 2000; Griffin et al. 2004; Bhaduri and 8 Skarstein 1997), Sociology (Bernstein 2010; Van der Ploeg 2013) and Anthropology 9 (Scott 1976, 1998; Netting 1993). However, interest in the subject of inequality in 0 access to land and other natural resources has experienced a recent recovery from new 1 Socio-Ecological and Political Ecology perspectives and opens up for new approaches 2 to inequality and its social and environmental impacts (Georgescu-Roegen 1977; 3 Hornborg 2003; Odum 2007; Hornborg et al. 2007; Schneider and McMichel 2010; 4 Garrabou et al. 2010; Tello et al. 2012; Foster and Holleman 2014; Neundlinger et al. 
1 2017), as well for studies of long-term socio-ecological transitions from a comparative

2 historical viewpoint (Fischer-Kowalski and Haberl 2007; Singh et al. 2013; González de

3 Molina and Toledo 2014; Haberl et al. 2016).

4 Taking advantage of bountiful local sources, and jointly with an interdisciplinary

5 group of historians, geographers and environmental scientists who have studied

6 different periods and subjects, this article presents a synthesis of the socioeconomic,

7 agricultural and environmental history of Mallorca from the Catalan feudal conquest in

81229 , to the financial crisis and parcelling of large landed estates of the end of the $19^{\text {th }}$

9 century. Our aim is to offer a synthesis of the Mallorcan transition from feudalism to

10 capitalism, which was characterized by the rise and fall of an agrarian class structure

11 based on large estates, while pointing out the similarities and contrasts with

12 neighbouring Mediterranean regions. This historical synthesis takes a long-term

13 perspective unlike the specific periods or issues studied by other specialists, which are

14 used as secondary sources. In addition, we use original data to illustrate our narrative

15 that adopts a broader interpretive scope which aims to connect demographic, socio-

16 economic and political drivers with environmental dimensions of land-use change.

17 We consider agroecosystems to be biophysical structures of human societies, a

18 'socially-constructed Nature' (González de Molina and Toledo 2014; Moore 2015).

19 Transitions are seen as historical shifts in the way societies organize their land-use

20 systems in a territory. Applying a Political Ecology standpoint, we highlight the role of

21 social inequality and conflict as key driving forces that transform nature-society

22 interactions through different landscapes and trade flows (Hornborg et al. 2007).

23 Landscapes are seen as context-specific results of multiple management practices

24 carried out by those who actually build them with their labour and knowledge, always

25 conditioned by rules of access that arise from a series of social conflicts over land

26 entitlements (Bisson 1977; Agnoletti 2006; Buswell 2013; Marull et al. 2015, 2016;

27 Agnoletti and Emanueli 2016).

28 These socio-ecological interactions lead to enduring legacies. For example,

29 settlement and land-use patterns stemming from early colonization processes had a

30 strong influence on resilience capacity to cope with general crises of the rural order

31 (Bloch 1970; Curtis 2016); with new taxation systems imposed by emerging kingdoms

32 and empires (Blickle 1997); and with the expansion of continental frontiers opened by

33 European colonialism (Moore 2011). Different 'windows of opportunity' to change the

34 prevailing agrarian class structures were opened by a series of social conflicts that arose 
1 in late feudalism, whose outcomes led to diverging paths among Mediterranean regions

2 which shared common institutions and land entitlements (Cazzola 2014).

3 The main question addressed in this long-term history is to explain how the agrarian

4 class structures, and society-nature interactions, were transformed from one

socioeconomic and agroecological turning point to the next. The chronology adopted rests on the role class conflicts played in the ensuing land ownership changes. We start with the socio-ecological rupture following the Catalan conquest of Mallorca in 1229. A second moment came about with the changes to landed property and landscape transformations resulting from the strong social struggles around feudal entitlements, tax burdens and peasant land-use rights in the Late Middle Ages. The landowners' victory led Mallorca towards a capitalist agriculture organized by large olive oilexporting estates that, in the 1580 s, became integrated in the Atlantic trade.

A third moment is marked by the long-term victory of land rent over agricultural wages along the transition towards agrarian capitalism in Mallorca. During the climatic, agrarian and demographic crisis of the $17^{\text {th }}$ century limits arose for the first time, leading to a downturn in the land rents of the Mallorcan nobility that was mainly overcome through the export-led expansion of olive groves. A fourth moment is the outbreak of the Spanish liberal revolution with the crisis of latifundia and the emergence of a new peasantry. The combination of heavy feudal exaction and high land rents that weighed on the backs of peasants, provoked a crisis at the end of the $18^{\text {th }}$ century, leading to liberal reforms during the $19^{\text {th }}$ century. The crisis of olive oil exports, the indebtedness of noble families, and the steady fall of agricultural prices alongside the European agrarian crisis of the end of the $19^{\text {th }}$ century led to a final process of 'peasantization' in the island via the purchasing of mortgaged lands by big bankers who then sold it on to small peasant families.

All these evolving farm systems and their distinct cultural landscapes were always shaped by peasants, either in times of revolt or by means of their everyday resistance

28 (Scott 1976). Despite their own heterogeneity, and thanks to their farming ingenuity that 29 took advantage of site-specific agroecological possibilities, the Mallorcan peasantry was able to endure the hoarding of land in the hands of large landowners over four centuries and to shape the contemporary landscapes of the island. In the following sections we outline the main dynamics and outcomes of each period, and we conclude highlighting the importance of the biocultural heritage of this Mallorcan peasantry. 
2 LAND USE PATTERNS AND LEGACIES OF THE ISLAMIC MAYÛRQA

3 The colonization of the island by Al-Andalus from the seventh century up to 1229 organized Mayûrqa as a tribal society with a strong local state based on taxation, and integrated into a dense network of Mediterranean trade. The leaders and the majority of the population were Muslim, but integrated with other cultural and religious minorities. Intensive cropping of irrigated orchards held by family farmers and communities was combined with extensive livestock raising of sheep, oxen, horses and mules across the tracts of arid land, with cultivation of grains, vines and olives in between. Population density was very low (estimated about 13.7 inhab. $/ \mathrm{km}^{2}$ ), and the settlement pattern consisted of small inhabited nuclei scattered across the island and the single big capital town Madîna Mayûrqa, where half of the island's inhabitants lived (Rullan 2002). The most salient feature of Mayûrqa's landscape was the polarization between highly intensive farming of small irrigated areas and a highly extensive and multiple-use farming of the remaining arid land (Glick 1995; Guichard 2010).

Mallorca is a karstic limestone island with no rivers where underground water was collected using wells and cisterns in flat areas, and by the qanât system in steeper territory - i.e. an excavated gallery with enough gradient to transport water from the aquifers down to vegetable gardens and orchards by gravity (Barceló 1998; Kirchner 2009). The small scale of these irrigation facilities was within the work capacity of a typical Al-Andalus village community (alqueria) or even of an extended family unit (rahal). Together with these irrigation techniques adopted from the Arabic-Muslim civilization, another important trait was the variety of introduced fruits and vegetables of Mediterranean, Mesopotamian and Indian origin (Glick 1996; Watson 1997; Decker 2009). An important legacy of the horticulture of Mayûrqa was a diet much richer in vegetables, fruits and fibre than any other in Europe at that time (Kirchner and Alshqour 2011; Mas and Soto 2015).

The Christian feudal conquest by the Aragon Crown in 1229 led to a deep rupture with the former land-use pattern of Mayûrqa - as the later Spanish colonization of pre-

30 Columbian America did on a larger scale. Throughout the following centuries of feudalism a new rainfed crop pattern of grains, olive groves and vineyards expanded across the island, while the Catalan king created a network of inland agro-towns to house peasant settlers. However it took several centuries to establish a completely new land use pattern, and to consolidate the novel agrarian class structure, in line with the 
1 pace of a growing population density that increased from 13.7 inhab. $/ \mathrm{km}^{2}$ in 1229 to

226.3 inhab. $/ \mathrm{km}^{2}$ by the end of the $16^{\text {th }}$ century (Rullan 2002: 168; Jover and Soto 2002).

3 This process depended on immigration of Catalan settlers, attracted by the colonizing

4 frontier that remained open up until the Black Death (1229-1348). Working with

5 different local natural resource endowments, migrant settlers established the distinctive

6 traits of new regions in the island (Figure 1).

[Insert Figure 1 here]

The Tramuntana Mountains that stretch from southwest to northwest, and the Llevant Mountains in the northeast corner were mainly devoted to olive groves, forestry, and summer pastures for sheep. The arid Migjorn in the southeast corner was allocated to winter pastures, together with some cereal plots and vineyards. In the inner plain, the Pla, rainfed cereal growing started to replace extensive livestock rearing. The Muslim hydraulic infrastructures were mainly located in the piedmont region known as Raiguer, between the Tramuntana Mountains and the Pla, supporting an intensive polyculture system where vegetable gardens, irrigated plots and arboriculture were associated with vineyards and grains. Two wetland areas located in the Palma and Alcudia bays were used for livestock grazing, and could not be converted into irrigated farming until the drainage processes undertaken in the $19^{\text {th }}$ and $20^{\text {th }}$ centuries. The city of Palma became a mercantile centre within the Catalan commercial system, which helps to explain the size and importance of the city in contrast with Mallorca's countryside economy (Riera 1986; Abulafia 2002; Buswell 2013).

FROM MAYÛRQA TO MALLORCA: SOCIOECOLOGICAL RUPTURES ENSUING FROM THE FEUDAL CATALAN CONQUEST (1229-1348)

The feudal colonization of Mallorca laid down new forms of land entitlement and labour control, which entailed a true socioecological rupture (Bartlett 1993; Glick 1995; Soto and Jover 2003). The invasion, led by the Catalan king with a troop of peasant and citizen soldiers steered by feudal lords, was very violent. Most of the Muslims defeated in 1229-31 refused to surrender, and survivors were enslaved and sold as war booty. Slavery became a salient feature of the new economy of Mallorca up to the $16^{\text {th }}$ century (Soto 1998; Mas 2012; Munney 2016). After the military conquest land was distributed among the victors. However, as landscape transformation was very slow, some major 
1 features of the inherited rural landscape remained for almost a century. The new

2 colonial power replaced the Muslim population with Catalan peasant settlers who were granted certain privileges (Mas and Soto 2015). A typical colonization frontier dynamic was put in motion, driven by five main forces. First, the feudal pyramid of power superimposed on peasant land concessions led to the typical dual land entitlement of emphyteusis: the king, the nobility and the church got a domain called 'eminent' that granted them the collection of tithes and feudal rents paid by the holders of the other, 'use' domain, land, together with other manorial charges and prerogatives derived from their position. Second, the water infrastructure, buildings, roads, place names, seeds, crops and agricultural know-how inherited from Mayûrqa was kept alive by the slaves and by other Muslims who had converted to Christianity in order to survive. Third, the royal privileges vested upon the new agro-towns, and on the city of Palma. Fourth, the gradual extension of rainfed grain cultivation, vineyards and olive groves under emphyteusis, which required peasant settlers to pay feudal rents to the lords, taxes to the king, and municipal levies to the city councils in return for the 'use' domain of the land. The final driver was the high social mobility and frequent failures ensuing from chain migration, while population densities remained low and the colonization frontier open, followed by a growing inequality when the frontier dynamic was closed in the $14^{\text {th }}$ century (Riera 1986; Portella 1998; Soto 1999; Jover and Soto 2002).

The king, the bishops and the feudal magnates left Mallorca shortly after conquest, and kept collecting tithes, manorial rents and taxes as a long-term reward for the resources invested in the invasion. Barons and knights stayed on the island and obtained the so-called 'landed estates of a knight' (cavalleries), divided into manor demesnes directly managed by their administrators and the rest of the land, where the 'use' domain was given over to peasants who paid seigneurial rents. These 'cavalleries' were endowed with manorial jurisdictions that these local knights were more eager to exert than the absentee feudal magnates (Montaner 1986). The Mallorcan manors were much less fragmented than the Catalan lordships from where this nobility came, but their coercion capacity was weaker than in Catalonia due to the privileges that had been offered to peasant settlers during the long-lasting open frontier. Former irrigation facilities were kept, usually privatized into the hands of noblemen or wealthy farmers, and many of them were adapted to propel manorial grain mills. The former Muslim dispersed housing pattern changed into more concentrated settlements in agro-towns 
1 where most of the peasants lived, with large isolated noble houses and manors

2 (cavalleries) situated in the countryside around.

3

4

Out of the former, extensively used, Muslim land use division between small irrigated areas and larger arid zones, a new one was born, with large noble estates surrounding the agro-towns and orchard belts intensively cropped by small peasants. The history of the Mallorcan landscape was, from then onwards, driven by the social entitlements and conflicts between these two opposing land users: the large estates in the ownership of noblemen and the remaining patchwork of parcels left in the hands of peasant families living in agro-towns (Soto and Jover 2003). While the population density remained low and the agricultural frontier open, feudal powers competed to lure in new settlers. Barons and knights had to reduce their pressure on peasants, and the king granted some liberties to agro-town dwellers in the form of certain privileges set down in writing in 1300 in the ordinances (Ordinacions) enacted by King Jaume II. The open colonization frontier gave the first colonizer-peasants an opportunity to prosper, giving rise to a stratum of well-off peasants who even had their own slaves. Whereas many of the first-comers were able to obtain larger farm units with irrigation facilities and mills, that combined cereal crops with vineyards and arboriculture, latecomers had to settle on smaller and poorer rainfed plots exclusively used for staple grains (Soto 1999; Mas and Soto 2015).

A distinctive trait of the polycultural farming of these middle and well-off peasants was the spread of vineyards and other Mediterranean arboriculture. The payment of tithes and feudal rents in kind, together with family sustenance, required cultivating a certain amount of grains. Cash crops allowed peasants to obtain the additional monetary income needed either to pay taxes to the king or to accumulate and invest. Accordingly, grain crops were combined with other cash crops like wine and olive oil and, especially, wool obtained from rearing flocks of sheep. Indeed, woollen textiles became one of the most important commodities of medieval Mallorcan trade (Deyà 1997; Abulafia 2002). The fate of this wealthy peasantry was linked to the opening and closing of the colonization frontier. While it remained open, nearly half of the population lived in the city of Palma, and the rest dwelled mainly in a great number of settlements along the valleys of the Tramuntana Mountains and the Raiguer piedmont, whereas the inner plain and the coast were highly depopulated. The well-off peasants of the inner Pla kept using most of the land for livestock rearing and transhumance, while intensive farming 
1 was mainly practised in the irrigated areas inherited from Muslim times (Jover and Soto 2 2002).

THE LATE MEDIEVAL AGRARIAN CRISIS AND AFTER: FROM MANORIAL CAVALLERIES TO LATIFUNDIST POSSESSIONS (1348-1580)

The agrarian crisis of the Late Medieval Period, and the strong social and political conflicts it brought, greatly determined the different paths opening up for agrarian capitalism all over Europe (Brenner 1976; Hilton 1990; Byres 1996, 2009). Mallorca stands out as an exception to the general trend that unfolded in the northwestern Mediterranean region - i.e. from the kingdoms of Valencia and Catalonia, to the north and centre of Italy, as well as the Languedoc and Provence in France - where agrosystems and cultural landscapes evolved towards the consolidation of peasant family farms. Despite differences in land ownership entitlements and tenancy contracts, in these regions a stratum of middle peasants and a growing number of smallholders developed a complex polyculture that combined diverse cash crops with staple foods produced for their own sustenance, usually supplemented with rural crafts and small industries. These diversified rural economies were able to sustain a dense network of commercial urban centres (Congost et al. 2003; Furió and García-Oliver 2010; Cazzola 2014).

The fate of Mallorca was very different to these middle-peasant paths that characterized the northeastern Iberian regions, and notably Catalonia where Mallorca's colonizers came from (Vilar 1963; Congost 2015). On the island a latifundist agrarian class structure became consolidated, more in line with the paths followed by other Mediterranean regions of southern Italy and Spain. Indeed, after the Catalan conquest the island became part and parcel of the Crown of Aragon, and then of the Spanish Empire which up until the $18^{\text {th }}$ century also included the kingdoms of Naples, Sicily and Sardinia. For these absentee monarchs and emperors Mallorca was basically considered a place from which to extract taxes for the royal treasury, in order to defray increasingly expensive wars or to cover the costly dowries required to make matrimonial alliances among the European crowns.

When the internal colonizing frontier contracted in the second half of the $14^{\text {th }}$ century, the royal tax burden on the plebeian families increased. Moreover, the local nobility - who were exempt from paying direct taxes - also strove to increase their own manorial charges, which were constrained by the straitjacket of the original allotments 
1 that granted peasants with an almost perpetual emphyteutic usufruct of the land. Even

2 before the Black Death hit the island in 1347-1348, many town councils had gone into 3 debt, as had many well-off peasants and smallholders, with many of them falling into

4 bankruptcy as a result of an ever greater levy of royal taxes (Cateura 2003, 2009). The

5 situation became unsustainable when nearly $20 \%$ of the population died during the

6 plague, and the population shrank from some 53,000 to 43,000 inhabitants.

7 After the Black Death the number of households fell by a quarter across rural areas,

8 and the gross agricultural output was reduced by a similar proportion. As a result the

9 feudal burden per inhabitant fell in the aftermath of the Black Death and until the end of

10 the $15^{\text {th }}$ century, and only started to grow steadily after the mid $16^{\text {th }}$ century (Duran 11 1982b, 66-67; López-Bonet 1990, 86-87, 93-94 and 2008; Portella 1993). All over

12 Europe the population decrease led to higher wages (Allen 2001, 2003; Allen et al.

13 2005; Pamuk 2007), so slaves became proportionally cheaper in the Mediterranean

14 (Heers 1981; Mas 2012). In a context of a dearth of labour, the stagnation and decrease

15 of wheat prices from 1375 to 1500 further squeezed the net incomes of wealthy farmers

16 who needed to hire farmhands. Indeed, in the prelude to the general feudal crisis of the

17 Late Middle Ages, the tax burden per inhabitant extracted by royal levies from Mallorca

18 grew more than agricultural productivity, cutting into the profit margins of wealthy

19 farmers. Hence, it was not only the load of feudal rents that crushed peasant economies,

20 but also the growing weight of a new set of royal taxes imposed on commercialization

21 of agricultural goods (Cateura 2003, 2006, 2009). This added an extra levy on farm

22 incomes that went beyond the reproductive capacity of most rural families. While in

23 other parts of Europe the overpressure of manorial charges triggered a general crisis of

24 feudalism (Bois 1978, 1984), in Mallorca the Late Medieval Agrarian Crisis was mainly

25 unleashed by this set of royal levies added to church tithes and other feudal burdens, all

26 exacted from a decreasing or stagnant agricultural surplus (Figure 2).

[Insert Figure 2 here]

The shortage of free labour during the population downturn also spurred the local nobility towards grabbing more peasant land in order to shift to labour-saving livestock rearing. The onerous levy of tax charges and tithes extracted by the king and a handful of absentee magnates, and the void left by the population decrease, offered them an opportunity to do so. A fierce conflict over tax burden distribution broke out between 
1 the powerful noblemen and patricians who lived in the city, and the rest of the

2 (plebeian) taxpayers who inhabited the agro-towns of the inner parts of the island. This

3 was similar to the fiscal subjection developed by north and central Italian cities over

4 their surrounding rural areas (or the contado). The inhabitants of the inner agro-towns and rural nuclei called themselves the 'Part Forana' in Catalan, i.e. 'outsiders' or even 'foreigners' from the city of Palma de Mallorca that was inhabited by a patrician elite of merchants and bankers who paid the royal levies and manorial charges to the king and feudal magnates in advance, and then administered the local collection of tithes and other manorial duties paid by the peasantry and craftspeople all over the island (Quadrado 1986[1895]).

The powerful patricians of the city displaced the tax burden on their own business onto the inner agro-towns. The town councils of these latter were in the hands of wealthier peasants who had arrived first at the colonizing frontier and accumulated more and better land. In 1315 they had founded and led a union, the 'Sindicat Forà', through which the inner agro-towns (Part Forana) obtained representation of the 'common people' in the parliament of the Kingdom of Mallorca (Gran i General Consell). Below these well-off peasants was a throng of poorer smallholders and craftspeople who suspected that their local authorities were displacing the tax burden onto them. Indeed, some wealthy farmers did take advantage of their pecuniary shortages, by acting as moneylenders, in a similar way to how some of the bankers of the city did with peasant private lands. Many town halls had to privatize part of their common lands to reduce the onerous debts that mortgaged the public finances of the Mallorcan agro-towns (Cateura 2009).

Hence, far from a simple dichotomy between lords and peasants the conflict involved at least five main stakeholders: the absentee king and feudal magnates, the local barons and knights, the merchant patricians of the city, the wealthy farmers, and the rest of the small peasants and craftsmen. Violent wrangling among noble families through gangs fighting each other (bandositats) added to these conflicts. At the same time, financial and marriage alliances were set up between merchant patricians and knights. The final outcome would depend on the strengths and weaknesses of the possible alliances among all these stakeholders.

In 1391 a revolt initially started as a pogrom against some Jewish lenders that ran simultaneously with pogroms in Seville, Cordoba, Toledo and Barcelona following the deliberate policy of the new Castilian monarchs to make Jews the scapegoat for social 
unrest (López-Bonet 1989; Valdeón 2000; Maíz-Chacón 2010). However, in Mallorca it soon escalated into protest against the local nobility and patricians who enjoyed fiscal privileges and who, as managers of the Mallorcan public debt, had accumulated a large amount of mortgage annuities (censals) that made the tax burden even more oppressive for taxpayers. The uprising ended in a bloody repression (López-Bonet 2008).

In 1450-1453 the rebellion of the Part Forana broke up when the so-called 'minor hand' (mà menor, meaning the poorer share) of the 'Sindicat Forà', together with the craftsmen of the city, rose up against the knights and patricians. The rebels besieged the city and sent a delegation to Naples to negotiate with Alfons el Magnànim, from where he then ruled a Mediterranean empire as King of Catalonia, Aragon, Valencia, Mallorca, Sicily, Sardinia and Naples. The monarch refused to negotiate and sent Italian mercenaries to quell the revolt with the help of the local troops of the nobility. An onerous fine was imposed on Mallorcan agro-towns, deepening even further the indebtedness of their inhabitants and councils (Morro 1995). This violent repression of the Mallorcan rebellion of 1450 by King Alfons el Magnànim sits in contrast with the reaction of his nephew, Ferran el Catòlic, to the Catalan peasant revolt (1462-1485). The Catalan Peasant War, led by a Union of Serfs (Sindicat Remença), ended with a royal arbitration that in 1486 liberated peasants from servitude by paying compensation to the lords, and hereafter weakened feudalism to a greater extent than in Mallorca (Vicens 1978; Vilar 1963; Freedman 1993; Congost 2015).

Another Mallorcan plebeian delegation was sent to complain again about the distribution of the tax burden in 1512, and this time Ferran el Catòlic ordered that a cadastral record be compiled to set up a fairer tax distribution. This prompted strong social tension in the island again, where the local nobility divided into gangs, bringing about a third revolt. The Germania (i.e., 'brotherhood') of 1521 was the last chance the Mallorcan plebeians had to alter the balance of forces. It began when several leaders of the craftsmen were imprisoned in the city of Palma, and duly liberated by an armed crowd shouting 'those who ought to must pay' ('qui deu que pac') (Duran 1982a; Mas 2013). The uprising received the active support of the peasantry of the Part Forana, including demonstrations by many women (Bernat 2005). This third Mallorcan revolt was concurrent with the Valencian Germania (1519-1522) and the Comuneros in Castile (1520-1521), and preceded the Great German Peasant War (1524-1525). The new Spanish king, the Emperor Charles the Fifth, reacted to all of these by ordering 
1 was crushed in 1523 (Seguí-Beltrán 2016). Heavy fines were imposed upon the agro-

2 towns, and the cadastral record ordered by the previous king in 1512 would not be compiled until the 1580 s.

In these three Mallorcan revolts the main issue was tax distribution, as well as the interest rates of the fixed annuity of mortgages (censals) paid as a result of the heavy public indebtedness derived from the levies paid to the king, which latter were only increased by the fines imposed after each defeat. Indeed, the financial assets of the Mallorcan public debt meant a significant share of the wealth was in the hands of the new local aristocracy. The peasantry rebelled against the city merchants and bankers, against the absentee landowners who contributed very little or nothing to the overall tax burden, and against the increasing alliance among those financial patricians and landed noblemen. In the background was a peasant struggle to preserve their 'use' dominion over the lands granted under emphyteusis against the increasing grabs of local nobility and citizen patricians (Duran 1982b).

15 The compulsory annuities paid on mortgage debts (censals) widened the land market 16 with the many forced sales and evictions from peasant lands they entailed (Mas 2008). Most wealthy farmers that survived the plagues went bankrupt. Their lands were taken by lenders or knights, who entered into very convenient marriage alliances. Municipal debts accumulated by town councils of inner agro-towns forced them to split and sell common land. Many land usages traditionally held in common as customary rights, and regulated by local ordinances on firewood collection, grazing, water troughs, rights of way or hunting, barely survived amongst the smallholders' puzzle of tiny plots (Barceló 1997; Brunet 1991). This enabled a new landed aristocracy to turn the former manorial cavalleries into new latifundist possessions, which were simultaneously kept in the 'use' and the 'eminent' emphyteutic domain (Bisson 1977; Jover and Morey 2003; Jover and Pons 2012, 2013). The distinctive feature of the new agrarian class structure was the land hoarding practiced by large noble estates and merchant patricians up to the end of the $19^{\text {th }}$ century.

A comparative historical view of the contrasting socioecological paths taken in Catalonia and Mallorca after the social agrarian crisis of the Late Middle Ages is very revealing. In Catalonia, besides the softening of late feudalism, medium and wealthy peasants obtained control over the abandoned land after the plagues (Congost 2015). In Mallorca the later colonization frontier had prevented serfdom; land distribution under emphyteusis had also prevented a rise of manorial charges, and the most profitable part 
1 of local manors held by barons and knights (cavalleries) were the demesnes under a full

2 ownership entitlement that encompassed the former 'use' as well as the 'eminent'

3 domains. The patrician-nobility alliance, taking advantage of the socioeconomic and

4 political crisis brought about by the royal tax burden, joined their forces and assets so as

5 to gain control over most of the former peasant 'use' domain of the land.

6

7 MALLORCA IN 1580: OLIVE OIL EXPORTS FROM LARGE ESTATES ON

8 THE BACKS OF SMALL PEASANTS

9 The cadastral records prompted by the plebeian revolts were finally compiled in 10 1576-1581, a source that provides a good picture of the agrarian structure of Mallorca 11 after the landowners' victory. Table 1 summarizes its most salient features, 12 differentiated among the rural regions of Mallorca, and excluding the city of Palma 13 where the new landed class lived. However, this is a very complex cadastral source, 14 which estimated taxpayers' wealth by recording net incomes to then capitalize them by 15 using different interest rates according to the character and amount of each income. The 16 wealth evaluated in this complex manner was allocated to where taxpayers lived, rather than to where their lands and assets were located. As a result some counter-intuitive data can be obtained, such as lower inequality indices in those municipalities where absentee landowners grabbed more land, leading to a greater disappearance of wealthy and middle peasants and making the remaining smallholders more 'equal' amongst themselves. To avoid confusion and present a broad and clear picture, Table 1 uses the proportion of total wealth recorded in each region that had been appropriated by the landed aristocracy living in the city of Palma as an inequality indicator. This data can be compared with the different cropland and livestock patterns according to the composition of tithes paid in each region, taking into account their different extents, population densities, and share of total wealth recorded in rural areas.

In the last quarter of the $16^{\text {th }}$ century more than a third of rural wealth was concentrated among large citizen landowners, which corresponded to more than half of

32 Mallorca's land (Montaner and Morey 1989: 259-271). Therefore a large share of the 
1 island was under a regime similar to what has been described as 'agrarian capitalism':

2 large ownership, short-term leasing contracts to manage them, and hired labour

3 (Brenner 1976; Epstein 2007; Van Bavel and Hoyle 2010). The epicentre of those large

4 possessions was the Tramuntana region, with $40 \%$ of rural wealth in the hands of big

5 landowners. Olive oil was 34\% of land produce there, and represented $94 \%$ of the

6 island's olive crop. Livestock produced another 23\% of income in the Tramuntana

7 region, $27 \%$ in the Llevant, and some $20 \%$ in the arid and isolated Migjorn where

8 middle peasants could survive a little better.

9 The second area where big landowners grabbed up to $27 \%$ of total wealth was the 10 inner Pla, mainly devoted to growing grains (79\%) and rearing sheep (linked to the 11 mountains through transhumance $-16 \%$ ). The lowest share of rural wealth taken by

12 citizen landowners was from the Raiguer, by far the most densely populated region, as

13 described by Binimelis (2014 [1593]), with the most diversified landscape that 14 combined wine (24\%), vegetables (11\%), grains (48\%), olive groves (5\%) and livestock $15(13 \%)$. Indeed $63 \%$ of all wine, and $35 \%$ of all vegetables were produced in this 16 reservoir of middle peasantry. The data makes apparent the dual character of the agrarian class structure that emerged after the crisis of feudalism, with a dominion of large possessions and a precariously surviving impoverished peasantry. Both farming systems gave rise to very contrasting but interlinked agroecosystems.

Under the new latifundist dominion a wealthy peasantry could only survive in certain towns of the Tramuntana Mountains (Pollença, Sòller), in some remote areas of the 22 Migjorn (Felanitx) and the Pla (Porreres), and to the greatest extent throughout the 23 Raiguer piedmont, better endowed with small irrigation facilities. Large possessions were managed by farmer-leaseholders (amos de possessió), usually coming from the former wealthy peasantry. This gave rise to true genealogies of farm managers, some of whom stayed in the same possession from the $16^{\text {th }}$ century onwards (Moll and Suau 1979, 1986; Suau 1991). They became another crucial channel that kept reproducing a biocultural legacy of peasant know-how - as shown by an important book on Mallorcan agriculture published in 1747 by a peasant farm-leaseholder named Montserrat Fontanet: L'Art de Conró (Ginard and Ramis 2015).

Under these circumstances landowners followed a management strategy of their possessions aimed at keeping wages low enough so as to ensure a substantial share of rent over the land products through the following three rules: 1) carrying out a more extensive farm management than that practised by small family farms around the agro- 
1 towns, so as to spare hired labour; 2) avoiding permanent leases of small plots to

2 tenants, so as to prevent the rise of the opportunity cost of smallholder peasants in the 3 labour market; and 3) establishing the so-called 'strict settlement' (fideïcomis in 4 Catalan, mayorazgo in Spanish) according to which the legacy inherited through 5 primogeniture became inalienable for the first-born heir who, as a tied-up trustee, had to 6 convey the inheritance to his descendants preserving its patrimonial integrity. This legal 7 framework protected the possessions from voluntary sales or forced evictions in case of 8 indebtedness and bankruptcy (Morey 1999). From the $16^{\text {th }}$ century onwards these rules 9 locked the socio-demographic and agroecological dynamics of Mallorcan farm systems into a strong conservative straitjacket. They framed the rumbling peasant resistance along the transition towards agrarian capitalism in Mallorca, which eventually emerged in a more open manner with the start of the liberal reforms of the $19^{\text {th }}$ century (Moll and Suau 1979; Grau and Tello 1985; Morey 1999).

14 In addition, major changes in the labour market were introduced. Accordingly, in the $1515^{\text {th }}$ century, as a response to labour scarcity following the Black Death, the new 16 Mallorcan landed class devoted a large share of their newly grabbed land to sheep rearing, taking control over the transhumance system previously dominated by well-off peasants. For as long as wages were higher than the cost of keeping slaves, big landowners resorted again to slavery. The replacement of slaves by wage labour only took place during the second half of the $16^{\text {th }}$ century, when the compression of peasant 21 plots at the outskirts of the inland agro-towns, and the resumption of population growth, 22 generated a large supply of cheaper free labour (Jover 2012). After stopping using 23 slaves in agriculture at the end of the $16^{\text {th }}$ century, the farmer-leaseholders hired domestic servants (missatges), other permanent farmhands and daily labourers (jornalers, collidores) to toil on their possessions. This workforce came from among the large numbers of smallholders that lived in agro-towns and could not sustain their families with just their own tiny plots. In some bigger towns (e.g. Manacor, Pollença,

28 Artà) rural industries could survive and provided another alternative to supplement

29 family incomes. From then on these two social agroecosystems, big possessions 30 extensively managed as large farms, and the patchwork of plots intensively farmed at the outskirts of agro-towns, paved the way for two contrasting cultural landscapes in Mallorca (Jover and Morey 2003). 
2 Within this polarized rural landscape, land use changes were propelled by changes in regional and international markets. The estate accounts of the aristocracy show that at the beginning of the $16^{\text {th }}$ century sheep rearing provided $71 \%$ of the landowners' rent, but fell to $43 \%$ by 1580 . Conversely, the importance of cereal crops grew from $29 \%$ to $57 \%$ (Jover 2012). Nonetheless, the composition of tithe collection offers clear evidence that the triumph of latifundia did not mean the disappearance of peasants and their biocultural heritage, which can be tracked in the persistence of crops such as vegetables and wine (Figure 3). Vineyards and arboriculture intercropped with cereals receded but survived in some municipalities, scattered within the belts of orchards and vegetable gardens around agro-towns. These small farms became reservoirs of traditional peasant knowledge and genetic resources within a complex, patchwork landscape. The polycultural mosaic of plots, intermingled with common land and other usages, provided ecosystem services to the whole community, though its distribution was uneven and sometimes conflicting (Jover and Morey 2003).

The expansion of sheep farming linked to wool exports to Italy and Levantine regions ended at the end of the $16^{\text {th }}$ century (Deyá 1998), but a new oportunity was opened by the rise in olive oil demand from Atlantic cities (Manera 1988; Bibiloni 1995). While these large estates kept exploiting forests, pastureland and olive groves, cereal crops increased either within the latifundia or on the outskirts of agro-towns, following the restoration of population growth and the upswing in wheat prices during the second half of the $16^{\text {th }}$ century (Figure 3 ). Nevertheless, grain production could not meet local consumption and cereals had to be imported (Manera 2001a). Within the possessions, arable land expansion resorted once again to utilizing peasant toil and knowledge through a type of clearance contract called 'rota'. The tenant ('roter') put a portion of forest or brushwood into cultivation, paying a low rent for a period of between 10 to 30 years, upon which the new cropland reverted to the large estate (Jover and Pons 2012).

INCOME INEQUALITY AND SOCIO-AGROECOLOGICAL LIMITS DURING 'EARLY GLOBALIZATION' (1580-1750)

We have seen that the historically contingent results of the social and political struggles spurred by the crisis of the feudal system from the Late Middle Ages to the $16^{\text {th }}$ century

34 (when the European colonial expansion began) were decisive for the paths taken 
1 afterwards. The $17^{\text {th }}$ century was again a time of crisis throughout Europe, and new

2 'windows of opportunity' were opened to distinct social groups (Wallerstein 2011;

3 Vries 2009, 2014; Duplessis 1997). During the first half of the $17^{\text {th }}$ century the landed

4 nobility took advantage of the rise in prices and falling real wages, whereas peasants

5 became impoverished (Kriedte 1983; Yun 1998; Parker 2013). The accumulated social

6 tensions blew up in the middle of the century. Peasant rebellions, urban uprisings and

$7 \quad$ state conflicts gave rise to a new institutional and global order (Elliott 1963).

8 Population growth and prices stagnated towards 1650 and went down until the

9 beginning of the $18^{\text {th }}$ century. There was a change in the structure of economic incentives, given that wheat prices decreased more than the price of other agricultural products whose relative profitability improved (Abel 1980; Vries 2009). Where the prevailing land distribution and institutional settings allowed, peasants sought to profit from this new juncture, by practising 'alternative agriculture' to cultivating grain

14 (Thirsk 1992). The agrarian innovations in the Dutch rural economy during the late 15 phase of its Golden Age (Vries 1974, 1997), and the start of the English Agricultural 16 Revolution, are two striking responses that initially grew the peasants' and yeomen's bargaining power, and their earnings and wages (Allen 1992, 2001, 2009). In these cases, the colder temperatures, from 1645 to 1715 along the period of climatic change known as the Maunder Minimum might have acted as an additional challenge that stimulated innovative farming responses (Vries 2014; Tello et al. 2017).

The Dutch trade connections with those emerging Atlantic economies where the global 'great divergence' started (Vries 2008, 2009; Allen 2001, 2009), together with their colonial routes, offered new opportunities to initiate processes of crop diversification and commercial specialization in vineyards and arboriculture in the Mediterranean bioregion (Llopis 2010; Sebastian-Amarilla 2013; Álvarez-Nogal et al. 2016). However, the extent of these agrarian changes would depend on the prevailing socio-institutional setting in each region and kingdom (Vries 2010; Acemoglu et al. 2005; Fusaro 2010). Once again the beginning of vineyard specialization in Catalonia, which led towards a less unequal rural society (Badia-Miró and Tello 2014; Tello and 30 Badia-Miró 2011), contrasts with the latifundist character of the export-led growth of Mallorcan olive groves. Here the land rent of the large possessions won a long-term victory over small peasant incomes and agricultural wages along the transition towards agrarian capitalism. At the same time, this highly unequal land and income distribution 
set some socio-agroecological limits to the reproduction capacity and growth of that agrarian class structure.

[Insert Figure 4 here]

5

The trends shown in Figure 4 illustrate the growing inequality in Mallorcan rural society throughout the transition to agrarian capitalism. They show the consolidation of a latifundist agrarian class structure where land rents obtained by the new aristocracy from their large possessions rose $16 \%$ in real terms from 1659 to 1750 . Even though land rents went down again from 1750 to 1800 , they did so at a slower pace than the reduction of wages. Conversely, real wages decreased 53\% from 1659 to 1800 . The ensuing $48 \%$ increase of the rental-wage ratio throughout the period clearly highlights the victory of the landowner rentiers of large possessions over the peasantry who, due to the lack of land to reproduce their families, had to draw on the labour market.

Population and agricultural production slowed in the first third of the $17^{\text {th }}$ century. The increasing difficulties that smallholder peasants faced to replenish soil nutrients, and keep up land yields make it apparent that their increasing deprivation of common natural resources - given that pastures, livestock and woods had been increasingly privatized - set a socio-agroecological barrier to the reproduction of their small farms (Jover 2012). The fierce droughts that became more frequent from 1591 to 1637 amplified the smallholders' difficulties, rendering many precarious farms economically unsustainable (Pastor-Oliver 2001; Jover 2011). At the same time land rent increases, combined with the rise in wages when the population stagnated (Figure 4), cut off the profits of and ruined many peasant leaseholders who had been managing the same big possessions over generations (Jover and Pons 2012). The crisis of the reproduction of smallholder peasants who provided labour, and of leaseholder farmers who managed the large estates, ended up calling into question the whole social fabric of Mallorcan agriculture. Exports of woollen textiles collapsed from 1620 onwards, and the ensuing ruin of these manufacturers deepened further the crisis of the rural and urban economy of the island (Deyá 1998; Bibiloni 1995).

The Mallorcan landed aristocracy, in contrast, were able to take advantage of the new opportunities that emerged in the international market through olive oil exports, which became the main cash crop exported from the island from the early $17^{\text {th }}$ century 
1 onwards (Figure 5). Olive oil played a key role in the Mallorcan balance of payments,

2 paying for grain imports, raw materials and manufactured goods from the $16^{\text {th }}$ to $18^{\text {th }}$ centuries (Manera 2001a). Domestic production of grains and legumes, cheese and meat, fibres and textiles, timber, firewood and charcoal covered a share of consumption, but imports were needed to fill the gap. The strategy to expand olive groves in order to export oil to foreign markets fuelled the power of the landed aristocracy of the island during the Ancien Régime (Manera 1988; Bibiloni 1995).

Most olive groves were located in the Tramuntana and Llevant mountains, which were deeply transformed with the construction of terraced fields. Terraces stretched from the limits of the inner plain to the holm oak forest, and the grasslands (Ampelodesmos mauritanica) located at some 600 m.a.s.l. (Bisson 1977; Ginés 1999). In these Mediterranean mountains, where droughts and heavy storms alternated seasonally and along the years, a complex drystone hydraulic system had to be built into the terraces to evacuate runoff and preserve soil from erosion (Grimalt et al. 1998). In some of the inland clay plains devoted to grain growing, drainage systems of deep furrows (albellons) were also built to evacuate runoff and prevent waterlogging (Estrany et al. 2010; Morey et al. 2010; Villalonga 2012; Jover 2013b). This drystone 'landesque capital', which remains one of the main features of the Mallorcan landscape, required a vast amount of labour supplied by the cheap workforce hired by the large possessions from the inland agro-towns of the island (Jover and Morey 2003).

\section{[Insert Figure 5 here]}

Only a tiny proportion of the Mallorcan olive oil was sold for human consumption. Most of it was exported to France and other European countries for soap making, to be burnt in oil lamps, or used as a lubricant (Manera 2001a). This was due to the high acidity of the Mallorcan oil caused by the long interval between harvesting and pressing because of the time required to pick the olives by hand and to transport the harvest across the large distances within the possessions. Olives inevitably started to ferment in the meantime, an outcome that might only have been minimized through taking on unaffordable numbers of farmhands. Indeed, the wages paid for reaping olives became a key component in the bookkeeping of these big possessions. The task required such high numbers of oil reapers that it exceeded by far not only their permanent farmhands, 
1 but the whole workforce available in the small surrounding villages of the Mallorcan

2 mountains as well. Thousands of labourers had to migrate seasonally from the agrotowns of the inner plain for several weeks in the winter to reap the terraced olives.

The books of accounts of the mountain possessions reveal that at an early stage they resorted to hiring women from smallholder families who sent their young daughters to work as olive reapers (collidores). Women's wages were half those of men, and for a girl or a child were a quarter. They comprised $60 \%$ and $5 \%$, respectively, of the daily labour hired by Mallorcan olive-exporter possessions (Jover 2013a, 2013b). This is a particularly relevant example of a general trait of the developing agrarian model adopted in the island under the latifundist hoarding of the land. The farm system of these large possessions could only remain profitable enough for the landed nobility if wages were kept very low. In turn, this meant keeping most of the rural population under conditions of poverty, and thereby prevented the growing demand that would be needed for any upsurge of 'industrious' activities (Vries 2008) to diversify the economy. Mallorca shared this fate with other regions, like the kingdoms of Naples and Sicily in southern Italy, or some southwestern areas of Spain, where cash crop exports that became highly profitable for a latifundist class precluded an advance towards industrialization. The contrast with Catalonia, where vineyard specialization reduced rural inequality and fostered the earliest industrial revolution in southern Europe, is very illustrative (Vilar 1963; Badia-Miró and Tello 2014).

However, when price trends changed downwards in the second half of the $17^{\text {th }}$ century crisis, even the nobility's earnings went into crisis (Segura and Suau 1984; Juan-Vidal 1990; Jover 2011; Jover and Manera 2009). The absolute value of real land rents in terms of wheat decreased from 1699 to 1739, triggered by price deflation (Figure 4). The landed aristocracy reacted by expanding the output of olive groves even more, from 15\% of Mallorcan land produce in 1695 to 22\% in 1785 (Figure 5; Bibiloni 1995; Jover 2002). This recovery strategy based on olive oil exports had, however, to face three challenges: the downturn of olive oil prices, the colder temperatures of the Maunder Minimum (1645-1715) that strongly hit olive harvests (Jover in press), and the real wage increases of 1719 to 1729 , and again of 1739 to 1750 , which raised costs and cut profits and land rents from olive oil production in the large possessions.

The latifundist agrarian structure was put in question, and new social possibilities emerged. The response was a massive hiring of female and child labour to reap the olives, and diversion of the exports mainly towards soap making due to the high acidity 
1 of much of the oil obtained. Moreover, big landowners, pressed by their financial

2 troubles, became obliged to reduce their land rents so as to keep their leaseholder

3 farmers, and to search for fresh cash by offering peasant smallholders some allotments

4 of small plots under emphyteusis (Jover and Pons 2012). Yet the Mallorcan nobility

5 soon discovered that the short-term easing obtained in this manner also jeopardized

6 their ruling class dominion in the mid and long-term - as shown by the reduction in the

7 rental-wage ratio that took place from 1739 to 1750 (Figure 4).

8 Indeed, the emphyteutic land allotments of small plots spread the intensive farming

9 of vineyards, vegetables and almond trees (Figure 5), mainly around some inland agro-

10 towns of the Pla, Migjorn and Llevant regions of the island (Manera 2001a). The

11 nobility stopped offering small allotments as soon as their budgetary situation was

12 balanced, and they could resort to olive oil exports as the main strategy to overcome the

13 long $17^{\text {th }}$ century crisis. In addition to this strategy the Spanish monarchy made two

14 policy interventions with the aim of salvaging the bad financial situation of the

15 aristocracy of their kingdoms. Firstly, the Crown of Aragon issued a decree in 1750

16 reducing the interest rate of the annuity mortgages (censals) from 5\% to 3\%. Secondly,

17 the Spanish monarchy started to intervene in the labour markets by setting wage caps.

18 Yet, as Figure 5 depicts, a certain amount of vine-growing in Mallorca continued,

19 together with an increasing role of two important novelties from 1755 to 1860: 1)

20 almond, fig and carob trees grown in intercropped association with grains; and 2)

21 leguminous crops, like broad beans (Vicia faba), incorporated into the crop rotations

22 practised on arable land. They signal an intensification of land use and differentiation of

23 agricultural produce adopted as a response to growing population density (56

24 inhab. $/ \mathrm{km}^{2}$ in 1860), mainly located in the peasant outskirts of agro-towns (Grau and

25 Tello 1985; Manera 2001a; Jover and Manera 2009). These agricultural innovations,

26 which sprang from the other side of the dual agrarian class structure of Mallorca, reveal

27 that, standing alone, the landed estates could never have been socio-agroecologically

28 sustainable. To put it bluntly, the majority of the population would not have survived on

29 the wages paid by the big possessions, which did not cover the full reproduction of the

30 hired workforce. The whole social fabric of rural Mallorca could only be maintained

31 owing to the fact that, below the landed estates of the nobility, there remained a peasant

32 stratum of smallholders striving to survive from their small plots. How far could such a

33 dual agrarian class structure grow? 
From 1595 to 1860 the overall agricultural product grew in real terms at a similar

2 pace as did the two-fold population increase (Figure 6). The agricultural population only multiplied by 1.67 , meaning an increase of about $20 \%$ in the output per agriculturally active inhabitant. This happened particularly when the demographic, socioeconomic and climate crisis of the $17^{\text {th }}$ century was overcome from 1655 to 1755 , due to a first wave of peasant allotments under emphyteusis, and again from the late 1700s until 1860.

[Insert Figure 6 here]

The different trends of the cropland product per inhabitant, and per agriculturally active inhabitant, highlight a modest increase in the non-agriculturally active population that earned a living through rural and urban industrious activities. However, after the demise of the local wool textile industry in the Late Middle Ages the island became a net importer of luxury manufactured products. Craftsmanship in agro-towns remained a complementary and usually part-time activity, only undertaken to provide for basic needs of the local poor rural population (Suau 1991; Manera 2001a). We came to the conclusion that the onerous compression of family incomes endured by peasant smallholders due to the land rent burden of the large possessions imposed strong limits on this mode of agricultural and industrious growth. This is apparent in the stagnation of the real agrarian product per inhabitant during the crisis of the $17^{\text {th }}$ century, and again with the downturn of land rents measured in terms of wheat equivalent from the mid$18^{\text {th }}$ century to 1800 (Figure 4 ).

The way out of the $17^{\text {th }}$ century crisis adopted by the Mallorcan big landowners raises an interesting question: how could such a latifundist farm system react when encountering diminishing returns? It is obvious that wages could not be reduced ad infinitum. When the biophysical surpluses obtained from the available land and 27 livestock started to stagnate or decrease, the share taken by the upper classes could no 28 longer stay the same. The land rents extracted by the landed nobility of the island, the tithes and feudal rents taken by feudal magnates from outside, and the tax burden of the Spanish king piled up on the backs of the peasants. A clear sign that the prevailing mode of agrarian growth had reached a socio-agroecological limit would be the outbreak of a fight among these participants over the peasant surplus, so as to retain their share of a diminishing amount. 
2 THE FINAL CRISIS OF COEXISTENCE OF LAND RENT AND FEUDAL

3 RENT: THE OUTBREAK OF LIBERAL REVOLUTION (1750-1860)

4 An important change took place as a result of the defeat of the kingdoms that had 5 supported the Austrian candidate against the Bourbon King who won the War of the 6 Spanish Succession (1701-1714). The three kingdoms formerly confederated in the 7 Crown of Aragon, i.e. Catalonia, Valencia and Mallorca, were punished in 1707-1716

8 with the imposition of a cadastral land tax by the Spanish Bourbon monarchs, while the

9 Castilian Crown and the Basque provinces remained exempted until the Liberal Tax 10 Law enacted in 1845. As this new direct land tax was introduced as war reparation, it 11 had to be paid by the formerly exempted nobility as well. This put a pressure on the 12 land rent share that ultimately rested on the backs of the peasantry, as well as the net 13 income of family farms. As the overall agricultural surplus began to stagnate or even 14 decrease, many Mallorcan smallholders faced the hard choice of either to endanger the 15 sustenance of their own families or defraud some of the burdens they bore. 16 Understandably, they started to dodge paying tithes and other feudal charges (Morey 17 2008).

18 Tithe evasion could be done in relative terms by shifting to lower taxed crops or to 19 those for which it was easier to dodge tax, an option that led to increases of tithes lower 20 than the actual growth of agricultural production. They could also defraud in absolute 21 terms, leading to a decrease of tithe collection. The overall volume of tithes stagnated 22 from 1695 to 1755 , and started to decrease from the mid-1700s up to the end of the 23 Napoleonic wars in 1818 (Figure 7). The tithe burden per inhabitant had already started 24 to fall from 1695 onwards, when it experienced an even higher decrease as a result of a 25 first wave of peasant allotments under emphyteusis, and of a greater resort to 26 complementary industrious activities. As mentioned above, the decline in the feudal 27 burden opened up opportunities for the expansion of new crops such as legumes, olive 28 oil, wine, almonds, carob, figs, vegetables, and rice (in some former wetlands of 29 S'Albufera bay) (Figure 5). 
These new crops prospered thanks to the ability of the peasants to dodge the old 2 feudal burden, making it evident that it was the everyday resistance of many Mallorcan smallholders that opened the way to agricultural innovation (Manera 1990; Morey 2006). Despite the complaints raised by bishops, who became significantly strong from the end of $18^{\text {th }}$ century onwards (Romero 1989), those crops would become the main ones in small peasant tenancies during the $19^{\text {th }}$ century (Cela-Conde 1979). We can take these trends in tithe collection as evidence that the prevailing mode of agricultural growth in Mallorca approached its socio-agroecological limits, once more, from 1750 up to the end of the Ancien Régime after the Napoleonic Wars (Buswell 2013).

The agroecological side of the challenge was how to increase agricultural output by adopting greater land-use intensity without preventing the replenishment of the nutrients extracted from the soil, and thus opening a socio-metabolic rift that would endanger farm reproduction in the long run. Smallholders, who endured the sustenance of the whole agrarian society, had to close the biophysical cycles of their agroecosystems by internally recycling most crop byproducts and with biomass taken from uncultivated land. Accordingly, smallholders' productivity was constrained by their land availability. They had to sustain farm reproduction by closing the internal agroecological loops such as soil nutrients and water content - in their tiny plots. According to Guzmán and González de Molina (2009) every socio-metabolic solution to farm sustainability has an associated land cost. In the case of the Mallorcan smallholders, access to livestock and soil nutrients was the main limiting factor that compelled them to carry out a heavy labour effort to supplement with other forms of organic (vegetable matter) fertilization and soil maintenance due to the scarcity of manure (Grau and Tello 1985).

Large estates could overcome this land cost more easily by internalizing the nutrient flows and the derived agroecosystem services within different possessions owned by the same landowner (Jover and Morey 2003; Jover and Pons 2012). In the possessions located in the mountains, olive trees associated with cereals were grown with pastures for livestock on top of the hills, and the forests in between grazed by pigs, as well as producing charcoal and timber. Sheep also fed on the green stems of olive trees and cereal stubble, leaving manure in the groves. Herds were moved in winter to inner and coastal possessions, thus closing biophysical flows on a greater regional scale. For these large estates, the true limits were not the land cost or the availability of organic fertilizers, but the cost of the labour they needed to hire (Jover 2013a, 2013b). 
Taking the two sides of this agrarian class structure together, we came to the

2 conclusion that the crucial socio-agroecological limits were actually set by the massive

3 hoarding of land exerted by large possessions, which confined smallholders to fringe

4 plots, too tiny to allow for their autonomous reproduction. Hence, the most decisive

5 limiting factor was social. This means that agricultural production could have been

6 increased, at least to some extent, by giving peasants wider access to land. However,

7 this would also have endangered the landowners' strategy of keeping wages very low in

8 order to maintain high land rents (Figures 4 and 6).

9 This dilemma was well understood by some members of the ruling classes of the island. When agricultural prices and land rents shrank during the $17^{\text {th }}$ century crisis, and wages rose due to population decrease, many possessions became indebted and some big families went bankrupt. A reaction to this was to use parts of the legacy not subject to strict-settlement, or ask the permission of the king to do so with the ones subjected, in order to offer small allotments under emphyteusis to peasants who would then pay the urgently needed cash as rents (censos). We have seen how a first wave of land allotments had already started in 1680, and then was suddenly stopped when the financial situation of the Mallorcan aristocracy improved from the mid- $18^{\text {th }}$ century onwards. Then a debate was opened between supporters and opponents on whether or not to continue the distribution of land allotments to small farmers under emphyteusis. It was a very revealing polemic (Morey 1999).

On one side stood the Mallorcan followers of the most outstanding figure of the 22 Spanish Enlightenment, Gaspar de Jovellanos (1744-1811), who was imprisoned in 23 Mallorca from 1801 to 1808. Jovellanos advocated overcoming the stagnation of 24 Spanish agriculture by a land reform that would distribute small plots of land to 25 peasants so that they would increase land-use intensity, agricultural products, private rents, and public taxes. In Mallorca this reformist view was aimed at bringing the island path near to the one Catalonia followed (Badia-Miró and Tello 2014). Contrary to this reformist view, a majority of Mallorcan landowners sided with those who argued - as an anonymous report wrote in 1798 - that 'the improvements made in Catalonia cannot be made in Mallorca because of the lack of farm hands' (Moll 1997, 138). Yet at that time population density in Catalonia was 37.6 inhab. $/ \mathrm{km}^{2}$, and in Mallorca 31.2 inhab. $/ \mathrm{km}^{2}$. Obviously the author was not talking of an absolute lack of farm hands, but rather of labour cheap enough to sustain a large enough flow of land rents to support the luxurious way of living of the Mallorcan nobility. 
Another text, written by the Mallorcan authorities as a preamble to a royal order that 2 established wage caps in 1753, clearly explained what was actually at stake: the growing product of land in smaller peasant plots would also increase their economic autonomy, and hence their opportunity cost in the labour market. According to the authors, such an increase in the bargaining power of labour suppliers had already given rise to 'the audacity of day labourers', who 'demand excessive prices for the short and defective work they perform, breaching the deals they made'. As a result, 'not equating the cost of reapers and labourers the price and value they may get, the total ruin of the island must follow'. Again they were actually talking about their own ruin as a class, not that of Mallorca. The royal order of 1753 established prison sentences for journeymen who refused to work for the salary cap enacted (Jover 2014, 365).

Only some small attempts were made in the direction claimed by the first group of enlightened reformers, such as the temporary tax incentives offered to plant vineyards in Mallorca, which succeeded in some municipalities like Felanitx and Porreres where a stratum of middle-class peasants did exist. But the actual increase of winegrowing was small (see Figure 5), and could only slightly reduce Catalan wine imports. The outcome clearly shows that having more vineyards would also require greater land availability for small vine-growers in a less unequal rural society - as happened in Catalonia (Badia-Miró and Tello 2014; Tello and Badia-Miró forthcoming). Under the socioagroecological blockade exerted by the big Mallorcan landowners to keep their rents high, as well as the desperate feudal reaction of the bishops and absentee magnates who, taking advantage of the political restoration of the Spanish absolutist monarchy after the Napoleonic Wars, raised the collection of tithes from 1818 to 1835 (Figure 7), a social reaction was provoked that unleashed liberal agrarian reforms in the island as well as all over Spain (Morey 1999, 2008).

Resistance from below, peasants' tithe evasion, and the liberal revolution (first attempted in 1820-1823, and finally carried out in 1833-1868) broke out of the former feudal straitjacket. The manorial system was abolished in 1836, and tithes in 1840. For a ruling class of Mallorcan landowners who had held their possessions as almost-private ownership over centuries, the Spanish liberal agrarian reform entailed very few changes at first. Landowners consolidated the legal status of their possessions as absolute individual property, and widened their extent by buying former Catholic Church land which was confiscated and sold by the new liberal Spanish monarchy in 1836-1851.

34 The little remaining common land that had survived former privatization through 
1 municipal indebtedness, was also confiscated and sold to wealthy landowners in 185521858 (Moll and Suau 1986).

All in all Mallorcan landowners did very well out of the Spanish liberal revolution, as shown by the Gini inequality indices of land ownership distribution recorded in the cadastres of 1818 and 1860 (Figure 8). They remained very high at 0.77 in 1818, and 0.84 in 1860 , on average for all available data - i.e. some ten points higher than in Catalonia (Garrabou et al. 2009; Tello and Badia-Miró, forthcoming). These Gini indices confirm that the highest inequality levels were in the Tramuntana $(0.80$ and 0.83 ) and Llevant (0.87 and 0.90) mountains where most oil-exporter possessions were located, while the lowest were in the Raiguer (0.71 and 0.61$)$ where a tiny middle class of winegrowing peasants survived. The cereal-growing inner plain remained in-between (0.75 and 0.73). Despite the different regional trends, on average inequality grew in Mallorca as a result of the liberal agrarian reforms.

[Insert Figure 8 here]

Taking the picture given by these cadastres from 1818-1860, we may consider small farms as those having less than 5 hectares (Tello 1983; Grau and Tello 1985) while large estates or possessions would be those above 50 hectares. Moreover, given that big landowners concentrated several possessions, their land properties amounted to between 100 and more than 1,000 hectares. The richer ones could take advantage of having their possessions located in diverse bioregions of the island (Bisson 1977; Cela-Conde 1979; Suau 1991; Jover and Morey 2003; Rosselló-Verger 2012).

\section{A FAILURE OF AGRARIAN CAPITALISM? THE LATE SHRINKAGE OF}

\section{LARGE ESTATES AND EXPANSION OF PEASANT FARMING (1860-1900)}

It was not the liberal agrarian reform as such that set in motion a deep change of land distribution and use in Mallorca. There were, however, three changes introduced by Spanish liberal governments which had a profound impact on the fate of the Mallorcan big landowners: land taxation, commodification, and financialization. The void left by tithes and other feudal charges, removed from the peasant surplus in 1836-1840, was immediately filled with the increase of public taxation after the Liberal Tax Law of 1845 that ended the former exemptions of the nobility - already lost in Mallorca in 1716 
1 - and extended the cadastral land tax throughout Spain. It imposed a high tax burden

2 indeed on the island (Morey 2008). The abolishment in 1820 of strict settlement in

3 legacies (fideïcomis or mayorazgo) exposed land assets of the Mallorcan aristocracy to

4 the vicissitudes of indebtedness and bankruptcy (Morey 1999). The new liberal law of

5 rural credit and mortgages of 1861, and the development of a modern banking system,

6 were going to have a great influence on the fortunes of the Mallorcan landed class

7 (Maixé 2001).

8 The financial problems of Mallorcan big landowners were not only of political

9 origin. Olive oil production and exports, to which they had resorted to tackle the socio-

10 agroecological limits to agricultural growth set by the prevailing latifundist agrarian

11 class structure, also faced increasing difficulties. From 1770-1780 onwards land rents

12 saw a contraction (Figure 2) that, once again, contrasted with the olive oil growth

13 experienced in other parts of the Mediterranean throughout the $19^{\text {th }}$ century, as well as

14 with the great winegrowing expansion experienced in Catalonia (Morey 1999; Morey

15 and Molina 2016; Garrabou et al. 2009). Many of the old olive trees were destroyed

16 during the climatic anomalies of the years 1770 and 1780, which coincided with the first

17 waves of the Dalton Minimum (Barriendos and Llasat 2003; Wagner and Zorita 2005;

18 Ferrer 2015). However, the question is why these olive trees were not replanted

19 afterwards? The answer lies in the inherent problems of the latifundist base of the olive

20 oil groves that existed on the island.

21 The Mallorcan contraction of olive oil exports coincided with the great surge in

22 demand for lubricants by the industrial revolution that had started in England (Allen

23 2009) and spread over the European continent and North America. Although

24 industrialization also put an end to its use for lighting in lamps, and globalization meant

25 a growing supply of other type of oil of colonial origin (Ramon-Muñoz 2000, 2013), the

26 main difficulty that prevented the Mallorcan olive oil producers from taking advantage

27 of the growing market for machinery lubricants was a very traditional feature: its high

28 acidity (Muendel 1995). The large proportion of olive oil too acid to be edible was due

29 to the large scale of the operation of reaping olives by hand in isolated mountain areas,

30 and transporting the harvest to pressing facilities. Being unsuitable for use as industrial

31 lubricant, Mallorcan olive oil production had to reorient its sales either towards

32 domestic food consumption or to local soap-making industries (Manera 2001a).

33 During the $19^{\text {th }}$ century agricultural expansion meant an absolute reduction in

34 livestock numbers all over Spain, which increased the price of animal fats traditionally 
1 eaten, like pork lard, and set in motion a dietary transition towards cheaper vegetable/olive oil - a true late discovery of the so-called 'Mediterranean diet' (Scheidel and Krausmann 2011; Infante-Amate et al. 2015; Soto et al. 2016). Yet, in order to obtain greater shares of edible olive oil, landowners had to invest more in picking, transporting and storing of olives as well as in better and faster pressing machinery - as expressed by the Mallorcan agronomists and other scholars of the time (Monlau 1877; Satorras 1878; Archduke Ludwig Salvator Von Habsburg-Lorraine 1897). The greater investment required rendered the profitability of this improved olive oil production very vulnerable to any steady decrease of prices. Indeed, this is what was going to happen during the European agrarian crisis at the turn of the $19^{\text {th }}$ century. It largely explains why it was then that the latifundist Mallorcan agrarian class structure, which had been established after the Germania defeat in 1521, went into serious bankruptcy.

The European-wide agrarian crisis at the end of the $19^{\text {th }}$ century was spurred by the so-called 'grain invasion' of cheap cereals and meat imports from North America and other recently colonized global frontiers (McMichael 2009). The reduction of freight costs initiated the First Globalization of 1870 to 1914 (O'Rourke and Williamson 1999). It led to the integration of a global market of staple food with reference prices established at the Chicago Board of Trade, where a futures market was set up for the first time (Cronon 1991). This, in turn, started a worldwide trend for persistent compression of the net value added retained by farmers in an increasingly urbanindustrial economy, which was going to persist throughout the $20^{\text {th }}$ century. The initial protectionist reaction of most European countries that raised tariffs on foreign imports, as Spain did in 1891, could soften but not suppress the downward trend of grain prices and land rents driven by global market integration (Abel 1980; Persson 1999; Allen 2011).

Not only did land rents of big landowners go down everywhere in Europe. At the same time land prices remained steady or even rose, shrinking the profitability of land as an asset (Offer 1991; Clark 2002). As a result, the European landed classes went into insurmountable financial troubles that led them to withdraw from agriculture and look to move their assets into other businesses. The end-of-the-century agrarian crisis gave rise to a general failure of agrarian capitalism in Europe (Koning 1994), and started a long-term process of 'peasantization' with or without new land reforms institutionally settled (Grigg 1989; Van der Ploeg 2008). Peasantization adopted different forms depending on the contexts. Where family farms already predominated, like in Catalonia, 
1 sharecropping and cooperatives spread (Garrabou et al. 2001, 2012; Planas 2016). The

2 Mallorcan aristocracy reacted to this third and definitive fall in their rents by selling 3 portions of their lands, an action which significantly shrank their big possessions for the 4 first time in their long history.

The liberal abolishment of strict settlement, and the changes introduced in mortgages and banking, played a key role in the process of spreading peasant allotments in Mallorca from the last quarter of the $19^{\text {th }}$ century to the first half of the $20^{\text {th }}$ (Bisson 1977; Rosselló-Verger 1982; Feo 1998). The lands that indebted landed families no longer wanted as their main asset were bought at a low price by rich bankers, such as Joan March (Banco de Crédito Balear 1973; Ferrer 2000; Manera 2005), who then sold them at a profit to Mallorcan peasants in smaller plots through emphyteutic leasing contracts (censos reservatius) that allowed a long-term payment through affordable annuities. The buyers of these lands were either former leaseholder-managers who took the opportunity to establish farms of their own, or smallholder peasants who dared to risk their savings and intensify their family labour to pay for additional plots. These peasant allotments gave rise to a spread of arboriculture alongside grains and legumes far beyond the outskirts of agro-towns, and to some regions like the Raiguer, where intensive peasant farming had been practised till then.

Thanks to selling almonds, figs, capers and grapes, the Mallorcan peasantry could earn the cash they needed to pay the annuities to buy the land, while grains, legumes, vegetables and carob allowed them to feed the livestock and provided food for their own family consumption. Some of these cash crops started to be exported, meaning that the ongoing changes of international trade during the First Globalization also offered Mallorcan peasants new opportunities to overcome the agrarian crisis at the end of the $19^{\text {th }}$ century - as was happening in other parts of Europe (Van Zanden 1991). This, in turn, entailed that a commercial and financial bourgeoisie started to take the lead in the Mallorcan economy and society. All in all, the ongoing 'peasantization' kept Mallorcan peasants in a subordinate place in this new capitalist order. In fact, many youths from smallholder families had to emigrate to North Africa and America due to the impact of the agrarian crisis, and the savings they sent home also helped to buy land allotments. As a result, most smallholders continued to combine cash crops with the sustenanceoriented staple food produced on their farms and in agro-towns.

Mallorcan exports changed dramatically, from an almost unique specialization in olive oil to a more diversified production pattern reflecting the new peasant landscape 
1 (Figure 2). Potatoes, capers, wine, dried apricots and figs, almonds, carob, tomatoes and 2 others crops were exported to London, Hamburg, Bremen, Stockholm, Barcelona and other Spanish ports (Rosselló-Verger 1959a, 1959b, 1964; Cela-Conde 1979; Manera 2001a). These cash crops were mainly supplied by the complex and multipurpose farming developed by new family farms that had been detached from former possessions. Nonetheless, given its high profitability, some large estates that remained farming incorporated these cash crops too (Suau 1991; Jover and Morey 2003). The large estates in the mountains, and the poor coastal areas, were very little affected by peasant allotments due to geographical factors like slope gradient, dryness and scant soil fertility that lowered profitability under the new farm system (Bisson 1977).

In addition to agricultural change, industry expanded from the mid- $19^{\text {th }}$ century onwards in sectors like agricultural machinery construction, food processing and finished goods such as shoemaking (Roca 1992; Manera 2001a). Two major transformations strengthened this industrial-agricultural nexus: new transport infrastructure, with the construction of a dense railway network and the enlargement of the port of Palma; and the draining of the wetlands of S'Albufera in Alcudia Bay and Prat de Sant Jordi in Palma. This gained land, plus other land put under modern irrigation systems, became a highly profitable investment as the new 'modern' industrial inputs and techniques were first implemented with the ensuing agroecological deterioration (Rosselló-Verger 1959a; Rosselló-Verger 1964; Cela-Conde 1979). Mallorca in general, and Palma's, population increased steadily, and house construction offered additional employment and investment opportunities. Real wages of industrial and agricultural workers grew, child mortality decreased, and life expectancy increased (Molina 2003; Moll et al. 2014).

\section{BIOCULTURAL HERITAGE}

28 As we have seen, the long-term change of the agrarian class structure in Mallorca has been featured by a double movement: from peasantization to latifundism, and from latifundism to peasantization. Along this process, peasant resistance has translated into cultural landscapes that still remain today. What stands out from a comparative historical viewpoint is the clear detachment of Mallorca from the middle-peasant path from feudalism to agrarian capitalism followed in Catalonia. Why did the Mallorcan 
1 offshoot diverge so much from where it originated? To find the answer it is worth

2 comparing Mallorca with other Mediterranean kingdoms also ruled by the Spanish

3 Empire so as to highlight similarities and dissimilarities in the way agrarian class

4 structures evolved depending on specific dynamics of colonizing frontiers and social

5 conflicts.

6 During late feudalism Castilian nobles enjoyed a growing share of the increasingly

7 centralised rent extracted by Spanish monarchs (Yun 2004). After the defeat of the

8 Comuneros revolt in 1521, peasants and craftsmen were heavily taxed to the point of

9 impoverishment, emptying a formerly dynamic northern Castile (Ringrose 1983;

10 Sánchez-León 1998; Yun 2004; Comín and Yun 2012). Colonization of the vast

11 depopulated territories of southern Castile, Extremadura and western Andalusia

12 remained weak, but accelerated from 1212 until the rapid military conquest of the $\mathrm{Al}$ -

13 Andalus Nasrid Kingdom in 1492. Conquering vast swathes of territory in a short period

14 allowed an oligarchic class to create large latifundia (Oto-Peralías and Romero-Ávila

15 2016), together with large urban settlements where smallholders and labourers provided

16 the workforce needed for shepherding, cereal growing and olive oil exports to the new

17 Atlantic frontiers of the Spanish Empire (Bernal 1988; Yun 2004). It should be

18 underlined that the high 'urbanization' rate seen here was only an expression of peasant

19 dispossession (Sánchez-León 2001; Epstein 2001).

20 The Muslim population surrendered, and stayed in some parts of Iberia. In eastern

21 Andalusia noblemen hoarded a lower proportion of land, and peasant communities got a

22 greater share in more scattered settlements and diversified agricultural landscapes

23 (González de Molina 2002; Infante-Amate et al. 2016). The Valencian moriscos were

24 displaced towards poorer inland areas, where they kept up a commercial diversified

25 farming, paying high taxes. The irrigated lands near the coast were colonized instead by

26 Catalan settlers housed in towns and cities. When these surrendered Muslims were

27 finally expelled from the Spanish monarchy in 1609, their lands were taken by landlords

28 and farmed by peasants who inherited their crops and know-how (Furió and García-

29 Oliver 2010).

30 The Mallorcan settlement in agro-towns somewhat resembles that of southern

31 Iberia, while the permanence of defeated Muslims brings the island's path close to that

32 of eastern Andalusia and Valencia - although in Mallorca they could only remain as

33 slaves, and were extinguished when landowners replaced them with hired labour.

34 However, in Mallorca the colonizing frontier remained open for a longer period and 
1 settlers were granted with privileges to a higher degree than in Andalusia. Indeed,

2 before the general crisis of feudalism, Mallorcan peasants enjoyed a status as good as 3 that which the Catalan peasantry would only acquire after the Late Middle Ages. So 4 they had to be dispossessed if a latifundist agrarian class structure were to be developed. 5 Moreover, the freedom acquired by peasants in Mallorca contrasted with the conditions 6 of serfdom in their Catalan lands of origin. During the $12^{\text {th }}$ and $13^{\text {th }}$ centuries a feudal 7 reaction imposed servitude in north-eastern Catalonia so as to hold wealthier peasants 8 back from migrating toward open frontiers (Freedman 1991). These contrasts confirm 9 the importance of the disjunction between the 'exit' or 'voice' options as a micro10 foundation of collective behaviour (Hirschman 1970, 2001); and also the contingent character of the outcome when the 'voice' was raised through class struggle and uprisings.

13 Abolition of servitude became the core issue of the Catalan Remença revolt of 14 1462-1472 and 1484-1485 (Vicens 1978; Feliu 2010). The organizational capacity of 15 the Catalan peasants can be compared with the later German Peasant War (Freedman 16 1993). Well-off Catalan peasants won this time (although a more radical wing that tried to abolish feudalism lost). Despite the persistence of feudal rents, peasant landowners became the major drivers of agrarian change there (Vilar 1963; Badia-Miró and Tello 2014; Congost 2015), turning Catalonia into a paramount case of bottom-up formation of agrarian capitalism (Byres 1996, 2009). The final defeat of the Mallorcan peasantry in 1521 led in the opposite direction. In short, history matters.

Ironically, the Mallorcan path based on big landowners, leaseholder managers and wage labourers might be considered much nearer to the agrarian structure that finally came to predominate in England (Shaw-Taylor 2012), rather than to the Catalan peasant path - in respect of which Robert Brenner made a blatant error when he considered that Catalonia followed an agrarian path similar to the English one (Brenner 1976; Torras 1983). Despite having a seemingly more 'modern' agrarian regime and higher urbanization rate, the product per unit of land and labour remained lower in Mallorca than in Catalonia (Manera 2001a; Jover and Manera 2009). The accumulation strategy of Mallorcan landowners rested on the appropriation of the 'cheap nature' (Moore 2015), land and labour, through dispossession and social repression, instead of introducing innovations to raise productivity. This largely explains why Catalonia became the earliest industrial region in Southern Europe (Badia-Miró and Tello 2014), and Mallorca did not. 
Yet Mallorcan economic growth attained levels comparable to Valencia, and 2 outperformed the poorer levels of other latifundist agrarian structures under Spanish rule in Castile, Andalusia, Naples and Sicily (Petrusewicz 1989; Bevilacqua 1990; Llopis 2004; Sebastián-Amarilla 2013; Álvarez-Nogal et al. 2016). This highlights again that, still whilst being defeated, the Mallorcan peasantry strove to survive, resist and improve in the long run.

When the big estates went into bankruptcy and started to sell a large share of their land at the turn of the $20^{\text {th }}$ century, there was still in Mallorca a peasantry ready to buy and farm these lands in a more intensive, polycultural and integrated manner. This late 'peasantization' proved that, despite their defeat in the Germania uprising of 1521, the Mallorcan peasantry had been able to survive for four hundred years enduring a harsh latifundist agrarian class structure. No doubt the hoarding of land exerted by the local nobility and mercantile patricians set limits to the purchasing capacity within the inner market of the island. The labour intensiveness and ingenuity of peasant smallholders allowed them 'to resist and grow' to some extent - as Carles Manera (1990) has said by resorting to multipurpose farming supplemented with industrious activities. Even if the scope of this economic growth was not enough, in any case, to open the way to an industrial revolution like the one that took place in Catalonia (Roca 1992; Manera 2001a), the main point is that the endurance of Mallorcan peasants, and their biocultural heritage, allowed them to remain alive until the financial failure of latifundism with the turn-of-the-century agrarian crisis.

The Austrian Archduke Ludwig Salvatore Von Habsburg-Lorraine arrived in Mallorca in 1867 , and he immediately fell in love with its landscapes and the people who had built them. He bought a beautiful estate in the Tramuntana Mountains, and moved to Mallorca for the rest of his life making it the base for his long navigation trips around the Mediterranean. The large list of books on different places and islands of this sea that he published contributed to spurring a first wave of German elite tourism in the region. His masterpiece was the nine-volume book Die Balearen in Wort und Bild published in 1897, with two of them dedicated to Agricultural Mallorca. The archduke had a broad scientific knowledge acquired during his youth in Tuscany, but he never dared to write a treatise telling Mallorcan farmers how to toil the land or improve their labour. What he actually did was to carefully collect and publish all that he learnt about the traditional know-how of Mallorcan peasants from observation and interviews with them, together with many official statistics and detailed engravings. His painstaking 
1 anthropological research made apparent how rich, deep and wise this peasant biocultural

2 heritage of Mallorca was (Archduke Ludwig Salvator Von Habsburg-Lorraine 1897).

3 The main lesson we draw from our long-term socioecological history is that, even

4 under a latifundist agrarian class structure, the agroecosystems of the island were

5 devised and run by the labour and knowledge of Mallorcan peasants. Farm leaseholder-

6 managers, agro-town smallholders, servants, day labourers, women reapers, herders,

7 lumberjacks and charcoal-makers were the people who created a cultural landscape

8 endowed with a rich biocultural heritage which - besides having helped turn the island

9 into a capitalist tourist resort during the last century (Cirer 2009) - now becomes an 10 important resource for a fairer and more sustainable future (Farina 2000; Altieri 2002;

11 Binimelis and Ordines 2008; IAASTD 2009; Martínez Alier 2011). In a further article

12 we are going to address the question of how this biocultural heritage evolved and 13 survived while enduring a capitalist mass tourist economy during the $20^{\text {th }}$ century. 14 Forthcoming research will delve deeper into this long-term environmental history, by 15 investigating more specific socio-metabolic indicators (Manera 2001b; Ginard and 16 Murray 2015; Ginard-Bosch and Ramos-Martín 2016) and socioecological data (Marull 17 et al. 2015, 2016).

\section{References}

Abulafia, D. (2002). A Mediterranean Emporium: the Catalan Kingdom of Majorca. Cambridge: Cambridge University Press.

Abel, W. (1980). Agricultural Fluctuations in Europe: from the Thirteenth to the Twentieth Centuries. London: Methuen.

Acemoglu, D., S. Johnson and J. Robinson (2005). 'The rise of Europe: Atlantic trade, institutional change, and economic growth'. The American Economic Review, 95 (3): 546-79.

Acemoglu, D. and J.A. Robinson (2006). Economic Origins of Dictatorship and Democracy. Cambridge: Cambridge University Press. Pub. 
1 Agnoletti, M. and F. Emanueli eds. (2016). Biocultural Diversity in Europe. New York: Springer.

Akram-Lodhi, H. and C. Kay (2010a). 'Surveying the agrarian question (part 1): unearthing foundations, exploring diversity'. Journal of Peasant Studies, 37(1): 177-202.

Akram-Lodhi, H. and C. Kay (2010b). 'Surveying the agrarian question (part 2): current debates and beyond'. Journal of Peasant Studies, 37(3): 255-84.

Allen, R.C. (1992). Enclosure and the Yeoman: the Agricultural Development of the South Midlands, 1450-1850. Oxford: Clarendon Press.

Allen, R.C. (2001). 'The great divergence in European wages and prices from the middle ages to the First World War'. Explorations in Economic History, 38(4): $411-47$.

Allen, R.C. (2003). 'Progress and poverty in early modern Europe'. Economic History Review, 61(3): 403-43.

Allen, R.C. (2009). The British Industrial Revolution in Global Perspective. Cambridge: Cambridge University Press.

Allen, R.C. (2011). Global Economic History: A Very Short Introduction. Oxford: Oxford University Press.

Allen, R.C., T. Bengtsson and M. Dribe eds. (2005). Living Standards in the Past. New Perspectives on Well-Being in Asia and Europe. Oxford: Oxford University Press.

Altieri, M. (2002). 'Agroecology: the science of natural resource management for poor farmers in marginal environments'. Agriculture, Ecosystems \& Environment, 93(1-3): 1-24.

Álvarez-Nogal, C., L. Prados De La Escosura and C. Santiago-Caballero (2016). 'Spanish agriculture in the little divergence'. European Review of Economic History, 20(4): 452-77.

Archduke Ludwig Salvator Von Habsburg-Lorraine (1897). Die Balearen in Wort und Bild geschildert. Würzburg und Leipzig: L. Woerl, available at https://archive.org/details/bub_gb_McoCAAAAYAAJ (accessed 4/03/2017). 
1 Aston, T.H. and C.H.E. Philpin eds. (1985). The Brenner Debate. Agrarian Class Structure and Economic Development in Pre-Industrial Europe. Cambridge: Cambridge University Press.

Atkinson, A.B., T. Piketty and E. Saez (2011). 'Top incomes in the long run of history'. Journal of Economic Literature, 49(1): 3-71.

Badia-Miró, M. and E. Tello (2014). 'Vine-growing in Catalonia: the main agricultural change underlying the earliest industrialization in Mediterranean Europe (17201939)'. European Review of Economic History, 18(2): 203-26.

Banco de Crédito Balear (1973). Banco de Crédito Balear: 1872-1972. Palma: Banco de Crédito Balear.

Barceló, G. (1997). 'Béns comunals i conflictes antisenyorials: les comunes de Muro i Santa Margalida (segles XVI-XVIII)', Bolletí de la Societat Arqueològica Lul.lilana, 53: 97-116.

Barceló, M. ed. (1998). The Design of Irrigation Systems in al-Andalus. Bellaterra: Universitat Autònoma de Barcelona.

Barriendos, M. and M.C. Llasat (2003). "The case of the "Maldà" anomaly in the western Mediterranean basin (AD 1760-1800): an example of a strong climatic variability'. Climatic Change, 61(1): 191-216.

Bartlett, R. (1993). The Making of Europe. Conquest, Colonization and Cultural Change, 950-1350. London: Penguin Books.

Bernal, A.M. (1988). Economía e historia de los latifundios. Madrid: Espasa-Calpe.

Bernat, M. (2005). 'Dones i revolta. La presència femenina a les Germanies (Mallorca 1521-1523)’. Bolletí de la Societat Arqueològica Lul.lilana, 61: 71-94.

Bernstein, H. (2010). Class Dynamics of Agrarian Change. Fernwood: Pluto and University of Michigan Press.

Bevilacqua, P. ed. (1990). Storia dell'agricoltura italiana in età contemporanea. Venezia: Marsilio.

Bhaduri, A. and R. Skarstein (1997). Economic Development and Agricultural Productivity. Cheltenham: Edward Elgar.

Bibiloni, A. (1995). El comerç exterior de Mallorca. Homes, mercats $i$ productes d'intercanvi (1650-1720). Palma: El Tall. 
1 Binimelis, J. (2014 [1593]). Descripció particular de l'illa de Mallorca e viles. Barcelona: Institut Cartogràfic de Catalunya.

Binimelis, J. and A. Ordines (2008). La pagesia illenca als albirs del segle XXI. Agricultura i postproductivisme a les Illes Balears. Pollença: El Gall.

Bisson, J. (1977). L'homme et la terre aux îles Baléares. Aix-en-Provence: Edisud.

Blickle, P. ed. (1997). Resistance, Representation, and Community. The Origins of the Modern State in Europe, 13th to 18th Centuries. Oxford: Oxford University Press.

Bloch, M. (1970). French Rural History: An Essay on its Basic Characteristics. Oxon: Routledge.

Bois, G. (1978). 'Against the neo-Malthusian orthodoxy'. Past \& Present, 79: 60-9.

Bois, G. (1984). The Crisis of Feudalism. Cambridge: Cambridge University Press.

Borrás Jr., S.M. ed. (2010). Critical Perspectives in Rural Development Studies. New York: Routledge.

Brenner, R. (1976). 'Agrarian class structure and economic development in preindustrial Europe'. Past \& Present, 70: 30-75.

Brenner, R. (2006). The Economics of Global Turbulence. London: Verso.

Brunet, P. (1991). 'Aproximaicó a l'estudi de la propietat comunal a l'illa de Mallorca'. Estudis Baleàrics, 40: 90-112.

Bryceson, D., C. Kay and J. Mooij eds. (2000). Disappearing Peasantries? Rural Labour in Africa, Asia and Latin America. London: Practical Action Publishing.

Buswell, R.J. (2013). Mallorca. The Making of the Landscape, Edinburgh-London: Dunedin.

Byres, T.J. (1996). Capitalism from Above and Capitalism from Below: Essays in Comparative Political Economy. London: Palgrave Macmillan.

Byres, T.J. (2009). 'The landlord class, peasant differentiation, class struggle and the transition to capitalism: England, France and Prussia compared'. The Journal of Peasant Studies, 36(1): 33-54.

Cateura, P. (2003). Sociedad y sistema fiscal del Reino de Mallorca (1360-1400). Palma: El Tall. 
1 Cateura, P. ed. (2006). Comprar, Vendre i Pagar al Rei. Els impostos indirectes al Regne de Mallorca, s. XIV-XV. Palma: El Tall.

Cateura P. ed. (2009). El crèdit i el sistema financer del Regne de Mallorca (segles $X I V-X V)$. Palma: Universitat de les Illes Balears.

Cazzola, F. (2014). Contadini e agricoltura in Europa nella prima età moderna (14501650). Bologna: CLUEB.

Cela-Conde, C.J. (1979). Capitalismo y campesinado en la isla de Mallorca. Madrid: Siglo XXI.

Chayanov, A.V. (1966). The Theory of Peasant Economy. Manchester: Manchester University Press.

Cirer, J.C. (2009). La invenció del turisme de masses a Mallorca. Palma: Documenta Balear.

Clark, G. (2002). 'Land rental values and the agrarian economy: England and Wales, 1500-1914'. European Review of Economic History, 6(3): 281-308.

Comín, F. and B. Yun (2012). 'From composite monarchy to nation-state, 1492-1914: An exceptional case?' In The Rise of Fiscal States. A Global History 1500-1914, eds. B. Yun, P.K. O’Brien and F. Comín, 233-66. Cambridge: Cambridge University Press.

Congost, R., Jover, G. and G. Biagioli eds. (2003). L'organització de l'espai rural a l'Europa Mediterrània: masos, possessions, poderi. Girona: CCG Ed.-AHR.

Congost, R. ed. (2015). The Catalan Mas: Origins, Transformations and the End of an Agrarian System. Girona: Universitat de Girona-Documenta Universitaria.

Cronon, W. (1991). Nature's Metropolis: Chicago and the Great West. New York: W.W. Norton.

Curtis, D.R. (2016). Coping with Crisis: The Resilience and Vulnerability of PreIndustrial Settlements. Oxon: Routledge.

Decker, M. (2009). 'Plants and progress: rethinking the Islamic agricultural revolution'. Journal of World History, 20(2): 187-206.

Deyá, M. (1997). La manufactura de la lana en la Mallorca del siglo XV. Palma: El Tall.

Deyá, M. (1998). La manufactura en Mallorca durante los siglos XVI y XVII. Palma: El Tall. 
1 Duplessis, R.S. (1997). Trasitions to Capitalism in Early Modern Europe. Cambridge: Cambridge University Press.

3 Duran, E. (1982a). Les Germanies als Països Catalans. Barcelona: Curial.

4 Duran, E. (1982b). 'Aspectes ideològics de les Germanies'. Pedralbes. Revista 5 d'Història Moderna, 2: 53-67.

6 Elliott, J.H. (1963). The Revolt of the Catalans: A Study in the Decline of Spain (15981640). Cambridge: Cambridge University Press.

8 Ellis, F. (1988). Peasant Economics. Cambridge: Cambridge University Press.

9 Ellis, F. (2000). Rural Livelihoods and Diversity in Developing Countries. Oxford: Oxford University Press.

11 Epstein, S.R. ed. (2001). Town and Country in Europe, 1300-1800. Cambridge: Cambridge University Press.

Epstein, S.R. (2007). 'Rodney Hilton, Marxism and the Transition From Feudalism to 14

Estrany, J., C. Garcia and R.J. Batalla (2010). 'Hydrological response of a small Mediterranean agricultural catchment'. Journal of Hydrology, 380(1-2): 18090.

Farina, A. (2000). 'The cultural landscape as a model for the integration of ecology and economics'. Bioscience, 50(4): 313-20.

Feliu, G. (2010). La llarga nit feudal. Valencia: Publicacions de la Universitat de 21 València.

22 Feo, F. (1998). 'Propiedad rústica en Baleares según el Registro de la Propiedad Expropiable (1933)'. Papeles de Geografía, 27: 41-59.

24 Ferrer, P. (2000). Joan March. Els inicis d'un imperi financer. Palma: Edicions Cort.

Ferrer, X. (2015). 'Freds, ocells, volcans, i capellans. Crònica dels ocells menorquins a la primera meitat del XIX'. Llibre Verd de Protecció d'Espècies a les Balears. Monografies de la Societat d'Història Natural de les Balears, 20: 589-96.

Fischer-Kowalski, M., and H. Haberl (2007). Socioecological Transitions and Global 30 Change: Trajectories of Social Metabolism and Land Use. Cheltenham: Edward Elgar. 
1 Foster, J.B. \& R.W. McChesney (2012). The Endless Crisis. How Monopoly-Finance Capital Produces Stagnation and Upheaval from the USA to China. New York: Monthly Review Press.

Foster, J.B. and H. Holleman (2014). 'The theory of unequal ecological exchange: A Marx-Odum dialectic'. The Journal of Peasant Studies, 41(2): 199-233.

Freedman, P. (1991). The Origins of Peasant Servitude in Medieval Catalonia. Cambridge: Cambridge University Press.

Freedman, P. (1993). 'The German and Catalan peasant revolts'. The American Historical Review, 98(1): 39-54.

Furió, A. and F. Garcia-Oliver (2010). 'Household, peasant holding and labour relations in a Mediterranean rural society. The Valencian country in the Late Middle Ages'. In Agrosystems and Labour Relations in European Rural Societies. (Middle Ages-Twentieth Century), eds. E. Landsteiner and E. Langthaler, 31-56. Turnhout: Brepols.

Fusaro, M. (2010). 'After Braudel: a reassessment of Mediterranean history between the Northern Invasion and the Caravane Maritime'. In Trade and Cultural Exchange in the Early Modern Mediterranean, eds. M. Fusaro, C. Heywood and M. SalahOmri, 2-42. London: Tauris Pub.

Galbraith, J. K. (2012). Inequality and Instability: A Study of the World Economy Just Before the Great Crisis. Oxford: Oxford University Press.

Galbraith, J. K. (2016). Inequality: What Everyone Needs to Know. Oxford: Oxford University Press.

Garrabou, R., J. Planas and E. Saguer (2001). 'Sharecropping and the management of large rural estates in Catalonia, 1850-1950'. The Journal of Peasant Studies, 28(3): 89-108.

Garrabou, R., E. Tello, X. Cussó and M. Badia-Miró (2009). 'Explaining agrarian specialization in an advanced organic economy: cereal production, consumption and trade in the province of Barcelona (Spain) in the mid-19 ${ }^{\text {th }}$ century'. In Markets and Agricultural Change in Europe from the 13th to the 20th Century, ed. V. Pinilla, 137-72. Thurnout: Brepols.

Garrabou, R., E. Tello and X. Cussó (2010). 'Ecological and socio-economic functioning of the Mediterranean agrarian systems in the middle of the 
nineteenth century. A Catalan case study (the Vallès county, 1850-1870)'. In Agrosystems and Labour Relations in European Rural Societies (Middle Ages20th Century), eds. E. Landsteiner and E. Langthaler, 119-54. Turnhout: Brepols.

Garrabou, R., J. Planas and E. Saguer (2012). 'The management of agricultural estates in Catalonia in the nineteenth and early 20th century'. Agricultural History Review, 60: 173-90.

Georgescu-Roegen, N. (1976). 'The institutional aspects of peasant communities: an analytical view'. In Energy and Economic Myths, ed. N. Georgescu-Roegen, 199-234. New York: Pergamon.

Georgescu-Roegen, N. (1977). 'Inequality, limits and growth from a bioeoconomic viewpoint'. Review of Social Economy, 35(3): 361-75.

Ginard, A. and A. Ramis eds. (2015). Montserrat Fontanet. Art de Conró. Mallorca, 1747. Pollença: El Gall.

Ginard, X. and I. Murray (2015). 'El metabolismo socioeconómico de las Islas Baleares, 1996- 2010'. In El metabolismo económico regional español, ed. O. Carpintero, 307-383. Madrid: FUHEM Ecosocial.

Ginard-Bosch, F.J. and J. Ramos-Martín (2016). 'Energy metabolism of the Balearic Islands (1986-2012)'. Ecological Economics, 124: 25-35.

Ginés, A. (1999). 'Agriculture, grazing and land changes at the Serra de Tramuntana Karstic Mountains'. International Journal of Speleology, 28(1): 5-14.

Glick, T.F. (1995). From Muslim Fortress to Christian Castle. Social and Cultural Change in Medieval Spain. Manchester: Manchester University Press.

Glick, T.F. (1996). Irrigation and Hydraulic Technology: Medieval Spain and its Legacy. Aldershot: Variorum.

González de Molina, M. ed. (2002). La Historia de Andalucía a debate. Vol. II. Granada: Diputación de Granda/Anthropos.

González de Molina, M. and V.M. Toledo (2014). The Social Metabolism: A SocioEcological Theory of Historical Change. New York: Springer.

Grau, E. and E. Tello (1985). 'Anàlisi de la producció agrària mallorquina en els seus dos aspectes fonamentals: l'oli i els cereals'. Randa, 18: 45-91. 
1 Griffin, K., A.R. Khan and A. Ickowitz (2002). 'Poverty and distribution of land'. Journal of Agrarian Change, 2(3): 279-330.

Griffin, K., A.R. Khan and A. Ickowitz (2004). 'In defence of neo-classical neopopulism'. Journal of Agrarian Change, 4(3): 361-86.

Grigg, D.B. (1989). English Agriculture: An Historical Perspective. Oxford: Basil Blackwell.

Grimalt, M. and FODESMA (1998). 'L'home com a factor geomorfològic a Mallorca. L'enginyeria popular amb finalitat antierosiva'. In Aspectes geològics de les Balears (Mallorca, Menorca i Cabrera), ed. J. J. Fornós, 423-34. Palma: Universitat de les Illes Balears.

Guichard, P. (2010). Al-Andalus: 711-1492. Paris: Fayard.

Guzmán, G. I. and M. González de Molina (2009). 'Preindustrial agriculture versus organic agriculture. The land cost of sustainability'. Land Use Policy, 26(2): $502-10$.

Haberl, H., M. Fischer-Kowalski, F. Krausmann and V. Winiwarter eds. (2016). Social Ecology. Society-Nature Relations across Time and Space. New York: Springer.

Harvey, D. (2010). The Enigma of Capital. And the Crises of Capitalism. London: Profile Books.

Heers, J. (1981). Esclaves et domestiques au Moyen Âge dans le monde méditerranéen. Paris: Fayard.

Hilton, R.H. (1990). Class Conflict and the Crisis of Feudalism (revised edition). London: Verso.

Hirschman, A.O. (1970). Exit, Voice, and Loyalty. Cambridge (Mass): Harvard University Press.

Hirschman, A.O. (2001). Crossing Boundaries. New York: Zone Books.

Hornborg, A. (2003). 'The unequal exchange of time and space: toward a nonnormative ecological theory of exploitation'. Journal of Ecological Anthropology, 7: 4-10.

Hornborg, A., J.R. McNeill and J. Martínez Alier (2007). Rethinking Environmental History. New York: Altamira Press.

IAASTD (2009). Agriculture at a Crossroads: Global Report of the International Assessment of Agricultural Knowledge. Science and Technology for 
Development. Washington, DC: Island Press, available at http://www.agassessmentwatch.org (accessed 4/03/2017).

Infante-Amate, J., D. Soto, E. Aguilera, R. García Ruiz, G. Guzmán, S. Cid and M. González de Molina (2015). 'The Spanish transition to industrial metabolism: long-term material flow analysis (1860-2010)'. Journal of Industrial Ecology, 19(5): 866-76.

Infante-Amate, J., I. Villa, F. Jiménez, M.M. Martín, D.M. López, G. Cunfer and M. González de Molina (2016). 'The rise and fall of the cortijo system: scattered rural settlements and the colonization of land in Spain's Mediterranean mountains since 1581. Journal of Historical Geography, 54: 63-75.

Jover, G. (1997). Societat rural i desenvolupament econòmic a Mallorca. Feudalisme, latifundi $i$ pagesia, 1500-1800, PhD Thesis. Barcelona: Publicacions de l'Universitat de Barcelona.

Jover, G. (2002). 'Ingresos y estrategias patrimoniales de la nobleza durante la crisis del seiscientos. Mallorca, 1600-1750'. In Fortuna y negocios. La formación y gestión de los grandes patrimonios (ss. XVI-XX), eds. $\mathrm{H}$. Casado and $\mathrm{R}$. Robledo, 89-120. Valladolid: Universidad de Valladolid.

Jover, G. (2011). 'Population, subsistence crisis and agrarian change in the island of Majorca, 1560-1650'. Histoire \& Mesure, 27: 51-74.

Jover, G. (2012). 'Tres notes sobre la demanda de treball assalariat a les possessions mallorquines durant el segle XVI'. In Les Possessions mallorquines. Passat $i$ present, eds. A. Morey and G. Jover, 209-31. Palma: Edicions Documenta.

Jover, G. (2013a). 'La difusión del trabajo asalariado infantil en la agricultura mallorquina: una aproximación a partir de los libros de cuentas de los predios oleícolas, 1700-1850'. In El Trabajo infantil en España, 1700-1950, ed. J.C. Borrás, 27-62. Barcelona: Icaria.

Jover, G. (2013b). 'Il fondi di Canet, 1723-1793. Investimenti ed expansione degli oliveti ne'll isola di Maiorca'. In Il mondo a metà. Studi storici sul territorio e l'ambiente in onore di Giuliana Biagioli, ed. R. Pazzagli, 151-68. Pisa: Edizioni ETS.

Jover, G. (2014). 'Després de les Noves Plantes: canvis i continuïtats a les terres de parla catalana'. In Actes del IC Xongrés de la CCEPC (Cervera, 21 I 22 de 
febrer de 2014), ed. N. Figueras and J. Santesmases, 351-68. Barcelona: Cosetània Edicions.

Jover, G. (in press). 'Was there an agrarian crisis in the last third of the 17th century in the Mediterranean World? The island of Majorca'. In ed. G. Beaur, Alternative Agriculture. A Reassessment. Thurnout: Brepols Publishers, in press.

Jover, G. and R. Soto (2002). 'Colonización feudal y organización del territorio, Mallorca, 1230-1350'. Revista de Historia Económica, 20(3): 437-75.

Jover, G. and A. Morey (2003). 'Les possessions mallorquines: una modalitat d'organització de l'espai agrari i l'explotació del treball'. In L'organització de l'espai rural a l'Europa Mediterrània: masos, possessions, poderi, ed. R. Congost, G. Jover and G. Biagioli, 127-238. Girona: CCG Edicions.

Jover, G. and C. Manera (2009). 'Producción y productividad agrícola en la isla de Mallorca, 1590-1860'. Revista de Historia Económica, 27(3): 463-98.

Jover, G. and J. Pons (2012). Possessions, renda de la terra i treball assalariat. L'illa de Mallorca, 1400-1660. Girona: Documenta Universitària.

Jover, G. and J. Pons (2013). 'Notes sobre resistència pagesa i paisatges agraris en els dominis de Lloseta-Aiamans i l'alqueria s'Estorell, 1428-1532'. Estudis d'Història Agrària, 25, 125-60.

Juan-Vidal, J. (1990). 'La evolución demográfica en Mallorca bajo los Austrias'. In Evolución demográfica bajo los Austrias. Actas del II Congreso de la Asociación de Demografía Histórica, Vol. 3, eds. V. Gonzalvez-Pérez, A. EirasRoel, M. Livi-Bacci, J. Nadal-Oller and J. Bernabeu-Mestre, 241-48. Alicante: Universidad de Alicante.

Kay, C. (2009). 'Development strategies and rural development: exploring synergies, eradicating poverty'. The Journal of Peasant Studies, 36(1): 103-37.

Kirchner, H. (2009). 'Original design, tribal management and modifications in Medieval hydraulic systems in the Balearic Islands (Spain)'. World Archaeology, 41(1): 151-68.

Kirchner, H. and R. Alshqour (2011). 'Watermills in the Balearic Islands during the Muslim period'. In Food in the Medieval Rural Environment, eds. J. Klápste and P. Sommer, 45-55. Turnhout: Brepols. 
1 Koning, N. (1994). The Failure of Agrarian Capitalism: Agrarian Politics in the UK, Germany, the Netherlands and the USA, 1846-1919. London: Routledge.

Kriedte, P. (1983). Peasants, Landlords, and Merchant Capitalists: Europe and the World Economy, 1500-1800. Cambridge: Cambridge University Press.

López-Bonet, J.F. (1989). 'La revolta de 1391: efectivament, crisi social'. In XIII Congreso de Historia de la Corona de Aragón, vol. II, 111-123. Palma: Institut d'Estudis Baleàrics.

López-Bonet, J.F. (1990). La Riquesa de Mallorca al segle XIV (Evolució i tendencies econòmiques). Palma: Consell Insular de Mallorca.

López-Bonet, J.F. (2008). 'Para una historia fiscal de la Mallorca cristiana (siglos XIIIXIV)'. Anuario de Estudios Medievales, 38(1): 101-184.

Llopis, E. (2004). El legado económico del Antiguo Régimen en España. Barcelona: Crítica.

Llopis, E. (2010). 'La Crisis Económica en la España del siglo XVII: La Decadencia de Castilla'. In Las crisis a lo largo de la historia, A. Furió ed., 47-96. Madrid: Publicaciones del Secretariado de Publicaciones e Intercambio Científico.

Maixé, J.C. (2001). 'Las Cajas de Ahorro y el desarrollo económico balear'. Estudis d'Història Econòmica, 17-18: 103-139.

Maíz-Chacón. J. (2010). Los judíos de Baleares en la Baja Edad Media: Economía y política. La Coruña: UNED.

Manera, C. (1988). Comerç i capital mercantil a Mallorca, 1720-1800. Palma: Consell Insular de Mallorca.

Manera, C. (1990). 'Resistir i créixer. Canvi econòmic i classes socials a la Mallorca del segle XVIII'. Randa, 26: 7-83.

Manera, C. (2001a. Història del creixement econòmic a Mallorca (1700-2000). Palma: Lleonard Muntaner.

Manera, C. ed. (2001b. Història ecològica a les Balears. Estudis sobre la energía, economía i medi ambient. Palma: Lleonard Muntaner.

Manera, C. (2005). 'Las cajas de ahorro y el crecimiento económico en Baleares, 18802000'. Papeles de Economía Española, 105/106: 169-87.

Martínez Alier, J. (2011). 'The EROI of agriculture and its use by the Vía Campesina'. Journal of Peasant Studies, 38(1): 145-60. 
1 Marull, J., E. Tello, N. Fullana, I. Murray, G. Jover, C. Font, F. Coll, E. Domene, V. Leoni and T. Decolli (2015). 'Long-term bio-cultural heritage: exploring the intermediate disturbance hypothesis in agro-ecological landscapes (Mallorca, c. 1850-2012)'. Biodiversity and Conservation, 24(13): 3217-51.

Marull, J., C. Font, E. Tello, N. Fullana, E. Domene, M. Pons and E. Galán (2016). 'Towards an energy-landscape integrated analysis? Exploring the links between socio-metabolic disturbance and landscape ecology performance (Mallorca, Spain, 1956-2011)'. Landscape Ecology, 31(2): 317-36.

Mas, A. (2008). 'Endeutament pagès i alienaicó de la terra a Mallorca durant la segona meitat del segle XV'. Bolletí de la Societat Arqueològica lul.liana, 64: 89-114.

Mas, A. (2012). 'La incidencia del mercado de esclavos en la estructura productiva de Mallorca (1300-1450)'. In Les esclavages en Méditerranée Espaces et dynamiques économiques, eds. F.P. Guillén and S. Trabelsi, 77-100. Madrid: Casa de Velázquez.

Mas, A. (2013). 'La Germania de Mallorca narrada per un contemporani'. Bolletí de la Societat Arqueològica Lul.liana, 69: 311-19.

Mas, A. and R. Soto (2015). 'Feudal colonisation and socio-ecological transition in Mayûrqa (Muslim Majorca) in the thirteenth century'. Continuity and Change, 30(3): 341-66.

McMichael, P. (2008). 'Peasants make their own history, but not just as they please ...' Journal of Agrarian Change, 8(2-3): 205-28.

McMichael, P. (2009). 'A food regime genealogy'. Journal of Peasant Studies, 36(1): 139-169.

Milanovic, B. (2011). 'A short history of global inequality: The past two centuries'. Explorations in Economic History 48(4): 494-506.

Mirowski, P. (2013). Never let a Serious Crisis go to Waste. How Neoliberalism Survived the Financial Meltdown. London: Verso.

Molina, R. (2003). Treball intensiu, treballadors polivalents. (Treball, salaris i cost de la vida: Mallorca 1860-1936). Palma: Conselleria d’Economía, Comerç i Indústria.

Moll, I. and J. Suau (1979). 'Senyors i pagesos a Mallorca (1718-1860/70)'. Estudis d'Història Agrària, 2: 95-191. 
Moll, I. and J. Suau (1986). 'Canvis i permanència de les institucions senyorials a Mallorca durant el segle XIX'. In Terra, treball i propietat. Classes agràries $i$ règim senyorial als Països Catalans, 66-106. Barcelona: Crítica.

Moll, I. (1997). 'Modelo de población y política demográfica. La Sociedad Económica Mallorquina de Amigos del País, 1779-1808'. Boletín de la Asociación de Demografía Histórica, 15(1): 125-63.

Moll, I., P. Salas, J.M. Pujades and E. Canaleta (2014). La lluita per la vida. Administració, medicina i reforma sanitària (Mallorca 1820-1923). Pollença: El Gall.

Monlau, J. (1877). Tratado de olivicultura, o del cultivo del olivo y de la obtención del aceite, escrito con aplicación al clima de España y más especialmente al de las Islas Baleares. Palma: Establecimiento Tipográfico de Pedro J. Gelabert.

Montaner, P. (1986). 'Les cavalleries mallorquines (segles XIII-XVIII)'. In Terra, treball i propietat: classes agràries i règim senyorial als Països Catalans, eds. N. Sales, P. Montaner, I. Moll and R. Garrabou, 42-65. Barcelona: Crítica.

Montaner, P. and A. Morey (1989). 'Notas para el estudio de la mano mayor mallorquina durante los siglos XVI y XVII'. Estudis Baleàrics, 34: 71-90.

Moore, B. Jr. (1967). Social Origins of Dictatorship and Democracy: Lord and Peasant in the Modern World. Harmondsworth: Penguin.

Moore, J.W. (2011). 'Transcending the metabolic rift: a theory of crises in the capitalist world-ecology', Journal of Peasant Studies, 38(1): 1-46.

Moore, J.W. (2015). Capitalism in the Web of Life. London: Verso.

Morey, A. (1999). Noblesa i desvinculació a Mallorca als segles XVIII i XIX: les repercussions de la legislació desvinculadora sobre els patrimonis nobiliaris. Palma: Universitat de les Illes Balears.

Morey, A. (2006). 'Continuïtat i canvis en les formes d'explotació i ús de la Gran Albufera de Mallorca (segles XVI-XX)'. In S'Albufera de Mallorca. Aspectes geogràfics, històrics i socioeconòmics, ed. R. Molina, 37-64. Palma: Conselleria de Medi Ambient.

Morey, A. (2008). 'Fiscalidad liberal, cambios en la distribución de la carga contributiva y transformación del modelo agrario. Mallorca (1845-1900)'. In Los tributos de la tierra. Fiscalidad y agricultura en España (siglos XII-XX), R. 
Vallejo and A, Furió eds., 517-40. Valencia: Publicacions de la Universitat de València.

Morey, A., J. Llabrés and A. Pascual (2010). 'Les tècniques per a l'aprofitament de l'aigua a les possessions mallorquines (segles XVIII-XIX)'. Estudis d'Història Agrària, 23: 117-36.

Morey, A. and R. Molina de Dios (2016). 'El retroceso del olivar en las Baleares: un itinerario a contracorriente de la evolución española (1800-1960)'. Historia Agraria, 68: 71-101.

Morro, G. (1995). Mallorca a mitjan segle XV. El Sindicat i l'Alçament Forà, Palma: Documenta Balear.

Muendel J. (1995) 'Friction and lubrication in medieval Europe. The emergence of olive oil as a superior agent', Isis, 86: 373-393.

Munney, K. (2016). 'Enchained in Paradise: slave identities on the island of Majorca, ca.1360-1390'. In Mediterranean Identities in Premodern Era, eds. J. Watkins and K.L. Reyerson, 121-38. New York: Routledge.

Netting, R. Mc. C. (1993). Smallholders, Householders. Farm Families and the Ecology of Intensive, Sustainable Agriculture. Stanford, CA: Stanford University Press.

Neundlinger, M., S. Gingrich, D. Güldner, F. Krausmann and E. Tello (2017). 'Land, food and labour in pre-industrial agro-ecosystems - a socio-ecological perspective on early 19th century seigneurial systems'. Historia Agraria, 71: $37-78$.

O’Rourke, K.H. and J.G. Williamson (1999). Globalization and History: The Evolution of a Nineteenth-century Atlantic Economy. Cambridge (MA): The MIT Press.

Odum, H.T. (2007). Environment, Power and Society for the Twenty-first century. New York: Columbia University Press.

Offer, A. (1991). 'Farm tenure and land values in England, c. 1750-1950'. The Economic History Review, 44(1): 1-20.

Oto-Peralías, D. and D. Romero-Ávila (2016). 'The economic consequences of the Spanish Reconquest: the long-term effects of Medieval conquest and colonization'. Journal of Economic Growth 21(4): 409-64.

Pamuk, S. (2007). 'The Black Death and the origins of the 'Great Divergence' across Europe, 1300-1600'. European Review of Economic History, 11(3): 289-317. 
1 Parker, G. (2013). Global Crisis. War, Climate Change and Catastrophe in the Seventeenth Century. New Haven: Yale University Press.

Pastor-Oliver, M. (2001). 'Rogatives i anyades: crisis de subsistència en els segles XVII-XVIII'. In Historia de Sant Joan, 125-142. Palma: Ajuntament de Sant Joan.

Persson, K.G. (1999). Grain Markets in Europe, 1500-1900. Integration and Deregulation. Cambridge: Cambridge University Press.

Petrusewicz, M. (1989). Latifondo: economia morale e vita materiale in una periferia dell'Ottocento. Venezia: Marislio.

Piketty, T. (2014). Capital in the Twenty-First Century. Cambridge (Mass.): Harvard University Press.

Planas, J. (2016). 'The emergence of winemaking cooperatives in Catalonia'. Business History, 58(2): 264-82.

Polanyi, K. (1977). The Livelihood of Man. New York: Academic Press.

Polanyi, K. (2001). The Great Transformation. Boston (Mass.): Beacon Press.

Portella, J. (1993). El Negoci feudal de Mallorca segles XIII-XV: drets i rendes de les senyories laiques i eclesiàstiques, PhD Thesis. Barcelona: Publicacions de la Universitat Autònoma de Barcelona.

Portella, J. (1998). 'Cómo se exporta el feudalismo: el caso de Mallorca'. In L'Incastellamento, eds. M. Barceló and P. Toubert, 85-98. Roma: École Française de Rome.

Quadrado, J.M. (1986[1895]. Forenses y ciudadanos. Historia de las disensiones civiles en Mallorca en el siglo XV. Palma: Font Editor.

Ramon-Muñoz, R. (2000). 'Specialization in the international market for olive oil before World War II'. In The Mediterranean Response to Globalization before 1950, eds. S. Pamuk and J. G. Williamson, 159-198. London: Routledge.

Ramon-Muñoz, R. (2013). 'Modernizing the Mediterranean olive-oil industry, 1850s1930s'. In The Food Industries of Europe in the Nineteenth and 20th Centuries, eds. D. J. Oddy and A. Drouard, 71-88. Farnham, Surrey \& Burlington (VT): Ashgate.

Riera, A. (1986). La corona de Aragón y el Reino de Mallorca en el primer cuarto del siglo XIV. Madrid: CSIC. 
1 Ringrose, D.R. (1983). Madrid and the Spanish Economy, 1560-1850, Berkeley: University of California Press.

Roca, J. (1992). 'Modernització agrícola i desenvolupament industrial. El cas de Mallorca (1850-1950)'. Estudis Baleàrics, 43: 109-18.

Romero, J.R. (1989). 'Señorío y propiedad en Mallorca en el tránsito de los siglos XVIII al XIX'. In Estructuras agrarias y reformismo ilustrado en la España del siglo XVIII, 349-81. Madrid: Ministerio de Agricultura, Alimentación y Medio Ambiente.

Rosselló-Verger, V.M (1959a). 'La huerta de Levante en Palma de Mallorca'. Estudios Geográficos, 77: 533-57.

Rosselló-Verger, V.M. (1959b). 'El Prat de Sant Jordi y su desecación’. Boletín Oficial de la Cámara de Comercio, Industria y Navegación de Palma de Mallorca, 77: $523-78$.

Rosselló-Verger, V.M. (1964). Mallorca. El sur y el sureste. Palma: Cámara Oficial de Comercio, Industria y Navegación.

Rosselló-Verger, V.M. (1982). 'Canvis de propietat i parcel.lacions al camp mallorquí entre els segles XIX i XX'. Randa, 12: 19-60.

Rosselló-Verger, V.M. (2012). 'La possessió, articuladora de l'espai rural. Imatge i realitat d'un sistema d'explotació esvaït'. In Les Possessions mallorquines. Passat $i$ present, eds. A. Morey and G. Jover, 19-46. Palma: Edicions Documenta.

Rullan, O. (2002). La construcció territorial de Mallorca. Palma: Editorial Moll.

Sánchez-León, P. (1998). Absolutismo y comunidad: los orígenes sociales de la guerra de los comuneros de Castilla. Madrid: Siglo XXI.

Sánchez-León, P. (2001). 'Town and country in Castile, 1400-1650'. In Town and Country in Europe, 1300-1800, ed. S.R. Epstein, 272-91. Cambridge: Cambridge University Press.

Satorras, F. (1878). Informe sobre el estado de la agricultura en la provincia de Baleares. Palma: Establecimiento Tipográfico de Pedro J. Gelabert.

Scheidel A. and F. Krausmann (2011). 'Diet, trade and land use: A socio-ecological analysis of the transformation of the olive oil system'. Land Use Policy, 28(1): $47-56$. 
1 Schneider, M. and P McMichel (2010). 'Deepening, and repairing, the metabolic rift'. Journal of Peasant Studies, 37(3): 461-84.

Scott, J. (1976). The Moral Economy of the Peasant. New Haven: Yale University 4 Press.

Scott, J. (1998). Seeing Like a State: How Certain Schemes to Improve the Human Condition Have Failed. New Haven, CT: Yale University Press.

Sebastián-Amarilla, J.A. (2013). 'El largo siglo XVII: crisis en España, depresión en Castilla'. In España en crisis: las grandes depresiones económicas 1348-2012, 59-96, eds. E. Llopis and J. Maluquer de Motes Barcelona: Pasado y Presente.

Seguí-Beltrán, A. (2016). 'Contra la diabólica desmandada. La reducción militar de la Germanía mallorquina. In Familia, cultura material y formas de poder en la España moderna, ed. M. García-Fernández, 797-805. Madrid: Fundación Española de Historia Moderna.

Segura, A. and J. Suau (1984). 'Estudi de demografia mallorquina: l'evolució de la població'. Randa, 16: 19-62.

Shanin, T. (1972). The Awkward Class. Oxford: Clarendon Press.

Shanin, T., ed. (1971). Peasants and Peasant Societies. Harmondsworth: Penguin.

Shaw-Taylor, L. (2012). 'The rise of agrarian capitalism and the decline of family farming in England'. Economic History Review, 65(1): 26-60.

Singh, S.J., H. Haberl, M. Chertow, M. Mirtl and M. Schmid, eds. (2013). Long Term Socio-Ecological Research Studies in Society-Nature Interactions Across Spatial and Temporal Scales. New York: Springer.

Soto, R. (1998). ‘UUna oferta sin demanda?: La esclavitud rural en Mallorca antes de la peste negra'. Historia Agraria, 21: 11-31.

Soto, R. (1999). 'Colonització i diferenciació pagesa a la Mallorca del segle XIII'. In Doctor Jordi Nadal. La industrialització $i$ el desenvolupament econòmic d'Espanya, vol. I, 375-401. Barcelona: Universitat de Barcelona.

Soto, R. and G. Jover. (2003). 'De la agricultura andalusí a la feudal: ¿una ruptura agroecológica? (Mallorca, 1230-1350)'. In La construcción histórica del paisaje agrario en España y Cuba, eds. A. Sabio and I. Iriarte, 25-52. Madrid: La Catarata. 
1 Soto, D., J. Infante-Amate, G.I. Guzmán, A. Cid, E. Aguilera, R. García and M. González de Molina (2016). 'The social metabolism of biomass in Spain, 19002008: From food to feed-oriented changes in the agro-ecosystems'. Ecological Economics, 128: 130-138.

Stiglitz, J. (2012). The Price of Inequality: How Today's Divided Society Endangers Our Future. New York: WW Norton \& Co.

Suau, J. (1991). El món rural mallorquí, segles XVIII-XIX. Barcelona: PhD Thesis at the Universitat de Barcelona.

Sweezy, P., M. Dobb, K. Takahashi, E. Hobsbawm, C. Hill, J. Merrington, G. Procacci, G. Lefebvre and R. Hilton (1976). The Transition from Feudalism to Capitalism. London: Verso.

Tello, E. (1983). 'La producció cerealícola a les petites explotacions pageses des Pla de Mallorca (1850-51)', Estudis d'Història Agrària, 4: 167-194.

Tello, E., R. Garrabou, X. Cussó, J.R. Olarieta and E. Galán (2012). 'Fertilizing Methods and Nutrient Balance at the End of Traditional Organic Agriculture in the Mediterranean Bioregion: Catalonia (Spain) in the 1860s'. Human Ecology, 40(3): 369-83.

Tello, E. and M. Badia-Miró (2011). 'Land-use profiles of agrarian income and land ownership inequality in the province of Barcelona in mid-nineteenth century'. Working Paper DT-SEHA 11-01, available at: http://citeseerx.ist.psu.edu/viewdoc/download?doi=10.1.1.1026.4326\&rep=rep1\&type=pdf (accessed 14/11/2017).

Tello, E., J.L. Martínez, G. Jover-Avellà, J.R. Olarieta, R. García-Ruiz, M. González de Molina, M. Badia-Miró, V. Winiwarter and N. Koepke (2017). 'The onset of the English agricultural revolution: climate factors and soil nutrients'. Journal of Interdisciplinary History, 47(4): 445-74.

Thirsk, J. (1992). Alternative Agriculture. A History from the Black Death to Present Day. Oxford: Oxford University Press.

Torras, J. (1983). 'Lluita de classes i desenvolupament del capitalisme (Nota sobre Agrarian Class Structure and Economic Development in Pre-Industrial Europe de Robert Brenner)'. In Ier Colloqui d'història agrária, 155-64. Valencia: Institució Alfons el Magnànim. 
1 Valdeón, J. (2000). El chivo expiatorio. Judíos, revueltas y vida cotidiana en la Edad Media. Valladolid: Ámbito.

Van Bavel, B.J.P. and R. Hoyle, eds. (2010). Rural Economy and Society in NorthWestern Europe, 500-2000. Turnhout: Brepols.

Van der Ploeg, J.D. (2008). The New Peasantries: Struggles for Autonomy and Sustainability in an Era of Empire and Globalization. London: Earthscan.

Van der Ploeg, J.D. (2013). Peasants and the Art of Farming. Halifa: Fernwood.

Van Zanden, J.L. (1991). 'The first green revolution: the growth of production and productivity in European agriculture, 1870-1914'. Economic History Review, 44(2): $215-39$.

Vanhaute, E. (2008). 'The end of peasantries? Rethinking the role of peasantries in a world-historical view'. Review, 31(1): 39-59.

13 Vicens, J. (1978). Historia de los Remensas. Barcelona: Vicens-Vives.

14 Vilar, P. (1963). La Catalogne dans l'Espagne moderne. Paris: SEVPEN.

Villalonga, J. (2012). 'Les reformes del patrimoni del marquès de Solleric a les possessions d'Alaró'. In Les Possessions mallorquines. Passat i present, eds. A. Morey and G. Jover, 283-98. Palma: Edicions Documenta.

Vries, J. de (1974). The Dutch Rural Economy in the Golden Age, 1500-1700. New Haven: Yale University Press.

Vries, J. de (1997). The First Modern Economy: Success, Failure, and Perseverance of the Dutch Economy, 1500-1815. Cambridge: Cambridge University Press.

22 Vries, J. de, (2008). The Industrious Revolution. Cambridge: Cambridge University 23 Press.

Vries, J. de, (2009). 'The economic crisis of the seventeenth century after fifty years'. Journal of Interdisciplinary History, 40(2): 151-94.

Vries, J. de, (2010). 'The limits of globalization in the early modern world", Economic History Review, 63(3): 710-33.

Vries, J. de, (2014). 'Crisis of the seventeenth century: the little ice age and the mystery of the 'Great Divergence'. Journal of Interdisciplinary History, 44(3): 369-77. 
1 Wagner, S. and E. Zorita (2005). 'The influence of volcanic, solar and $\mathrm{CO}^{2}$ forcing on

2

3

6

7

8

9

10 Dynamics, 25(2): 205-18.

Wallerstein, I. (2011). The Modern World System II; Mercantilism and the Consolidation of the European World-Economy 1600-1750. Berkeley: University of California Press.

Watson, A.M. (1997). Agricultural Innovation in the Early Islamic World. Cambridge: Cambridge University Press.

Wolf, E.R. (1966). Peasants. Englewood Cliffs, NJ: Prentice Hall.

Wolf, E.R. (1982). Europe and the People without History. Berkeley, CA: University of California Press.

Yun, B. (1998). 'From political and social management to economic management? Castillian aristocracy and economic development, 1450-1800'. In Aristocracy, Patrimonial Management Strategies and Economic Development, 1450-1800, C. E. Núñez ed., 55-68. Sevilla: Universidad de Sevilla.

Yun, B. (2004). Marte contra Minerva. El precio del Imperio español. ca. 1450-1600. Barcelona: Crítica. 


\section{$1 \quad$ List of Figures}

2 Figure 1 Map of the main natural regions of the island of Mallorca (Spain)

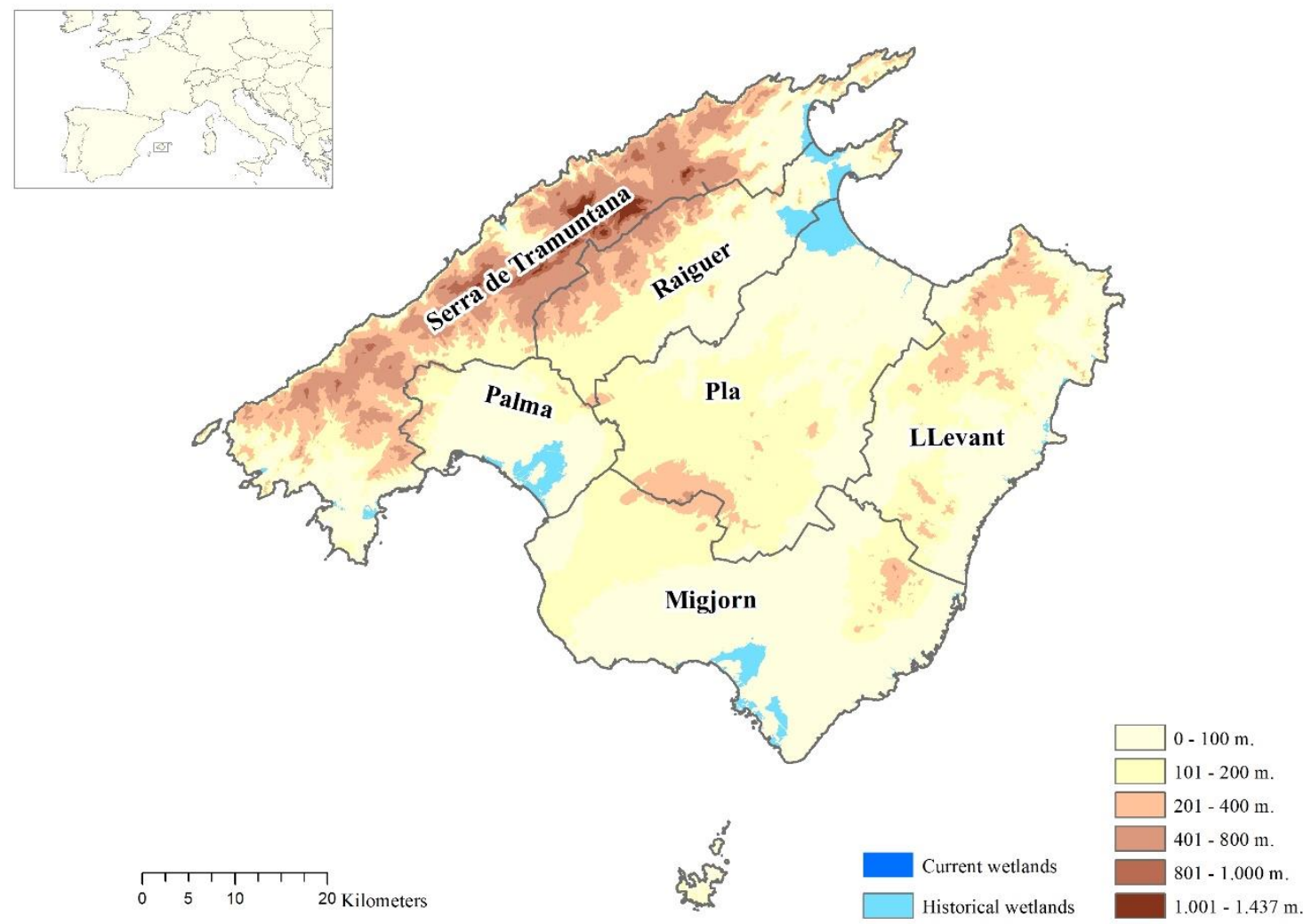

Source: Own data. 
1 Figure 2 The unleashing role of the royal tax burden in the outbreak of the Late

2 Medieval Agrarian Crisis in Mallorca (1372-1517)

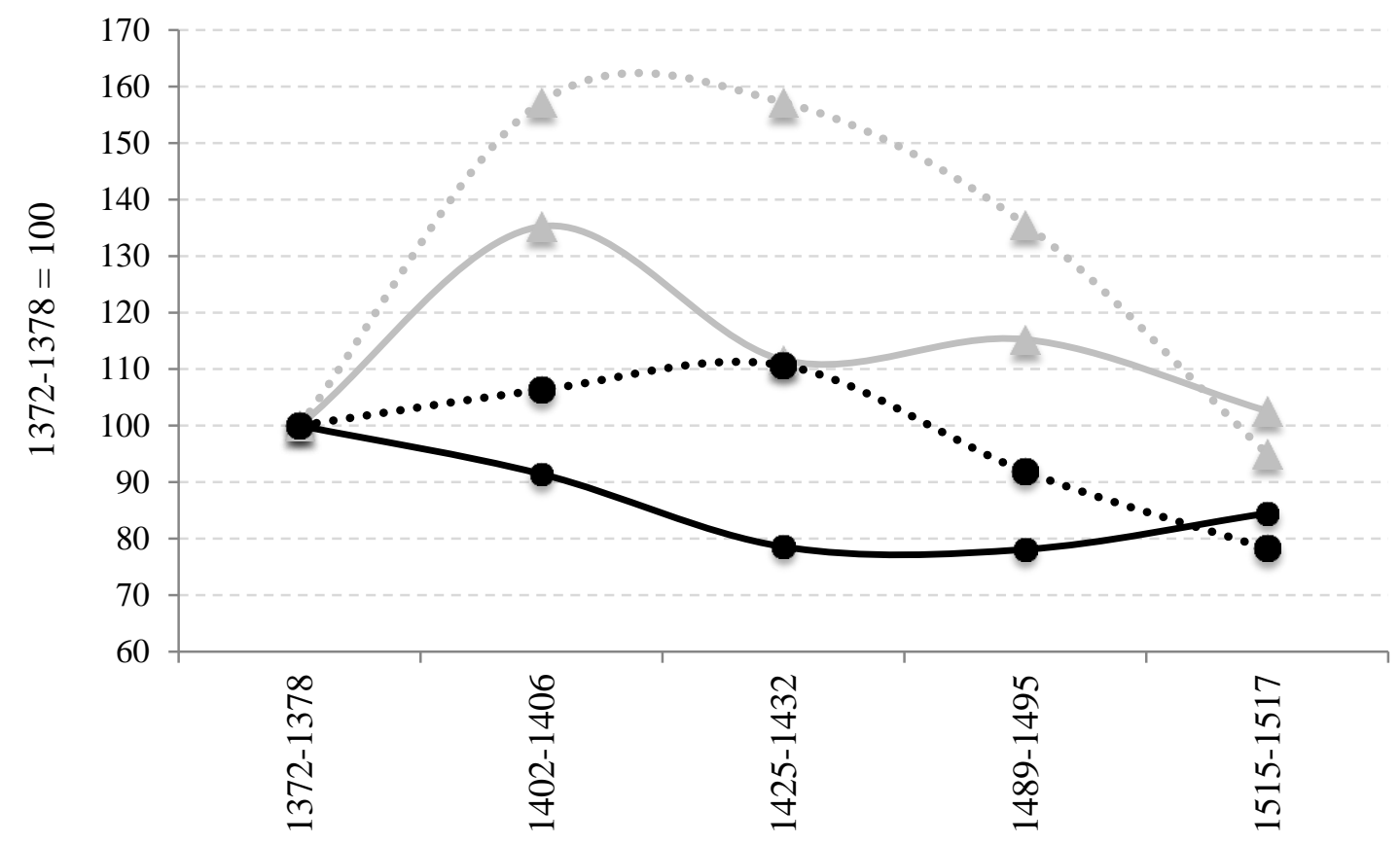

- A. Royal levy in wheat real terms

$\rightarrow-B$. Tithes collected in wheat real terms

$\cdots$ C. Royal tax burden per inhabitant in wheat real terms (A/population)

••・D. Tithe burden per inhabitant in wheat real terms (B/population)

3

4 Sources: Own data, with tithes and population data taken from López-Bonet (1990, 86-

5 87, 93-94, 107); Portella (1993, appendix), and Duran (1982b, 66-67); and tax data

6 taken from Cateura (2003, 171-172, 2006, 2008, 2009) and Morro (1995).

7 
1 Figure 3 Changes in the composition of agricultural product according to tithes before

2 and after the Late Medieval Agrarian Crisis in Mallorca (1325-1575)

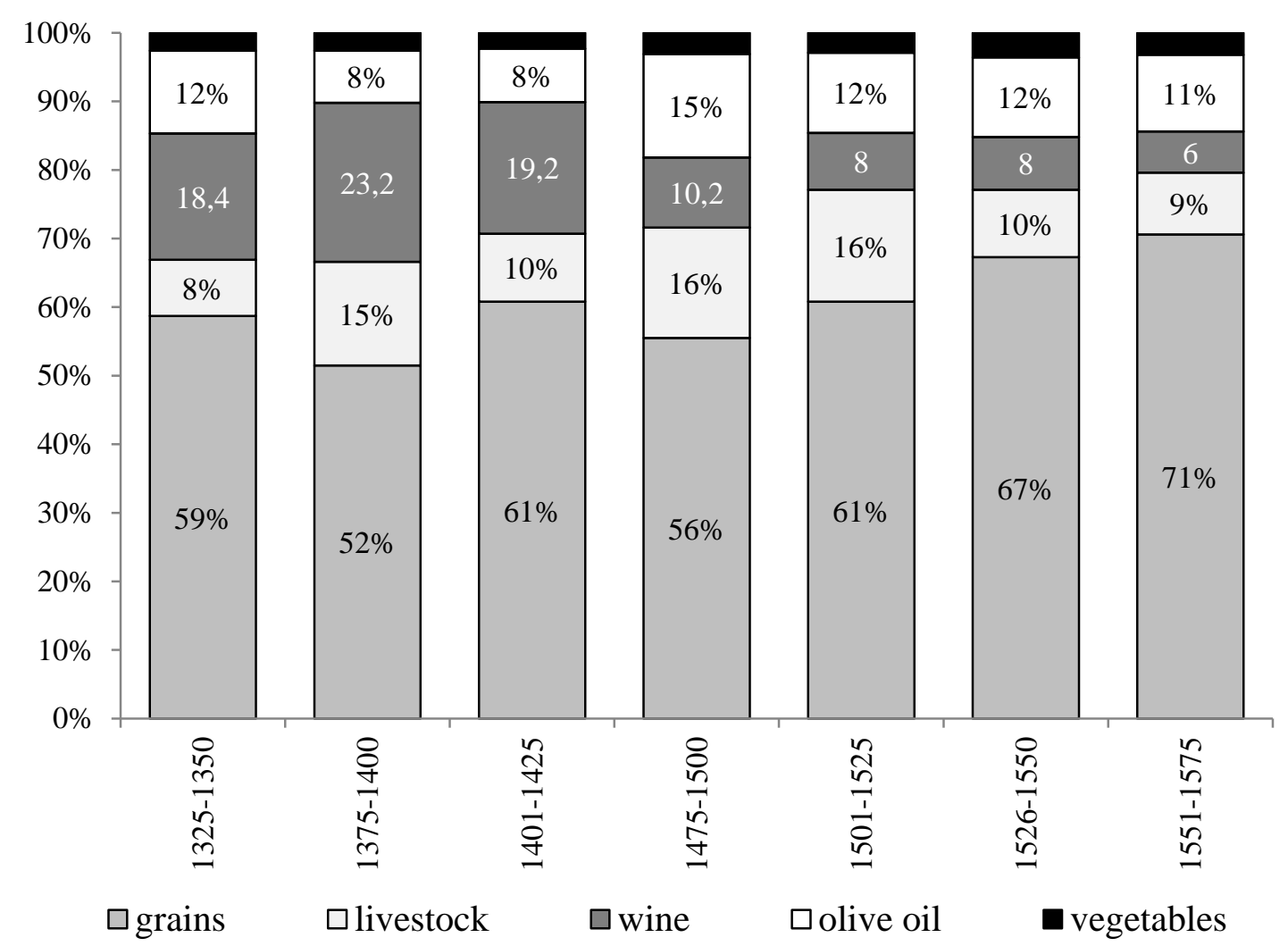

3

4 Sources: Own data, from López-Bonet (1990, 93-94) and Portella (1993, appendix).

5

6

7

8

9

10

11

12

13

14 


$$
\begin{gathered}
\text { Share Share of } \\
\text { of each wealth of } \\
\text { region the region } \\
\text { over the owned by }
\end{gathered}
$$

\begin{tabular}{|c|c|c|c|c|c|c|c|c|c|}
\hline & $\begin{array}{r}\text { Share } \\
\text { of } \\
\text { island's }\end{array}$ & Population & $\begin{array}{r}\text { total } \\
\text { wealth } \\
\text { of the }\end{array}$ & $\begin{array}{l}\text { noblemen } \\
\text { living in } \\
\text { the city of }\end{array}$ & Share o & fagric & Iltural pr & roduce of th & he region \\
\hline & $\begin{array}{r}\text { extent } \\
(\%)\end{array}$ & $\begin{array}{r}\text { density } \\
\left(\text { inhab. } / \mathrm{km}^{2}\right) \\
\end{array}$ & $\begin{array}{r}\text { island } \\
(\%)\end{array}$ & $\begin{array}{r}\text { Palma } \\
(\%) \\
\end{array}$ & $\begin{array}{r}\text { Olive oil } \\
(\%)\end{array}$ & $\begin{array}{r}\text { Wine } \\
(\%)\end{array}$ & $\begin{array}{r}\text { Grains } \\
(\%)\end{array}$ & $\begin{array}{r}\text { Livestock } \\
(\%) \\
\end{array}$ & $\begin{array}{r}\text { Vegetables } \\
(\%) \\
\end{array}$ \\
\hline Tramuntana & 28.2 & 24.8 & 38.0 & 39.7 & 33.5 & 1.0 & 40.9 & 23.1 & 1.5 \\
\hline Raiguer & 8.5 & 58.3 & 14.3 & 18.4 & 4.0 & 23.8 & 48.3 & 12.8 & 11.1 \\
\hline Pla & 23.3 & 33.3 & 26.6 & 35.4 & 0.1 & 2.0 & 79.2 & 15.6 & 3.1 \\
\hline Llevant & 16.1 & 15.7 & 9.1 & 39.7 & 0.2 & 0.9 & 70.5 & 27.2 & 1.2 \\
\hline Migjorn & 23.9 & 17.1 & 12.0 & 27.2 & 0.1 & 1.5 & 76.4 & 19.7 & 2.3 \\
\hline MALLORC & 100.0 & 26.3 & 100.0 & 34.20 & 7.7 & 3.5 & 65.8 & 20.0 & 3.0 \\
\hline
\end{tabular}

Source:Own data, taken from Binimelis (2014[1593]), Jover (1997: 241-51). 
1 Figure 4 The victory of land rent over agricultural wages along the transition

2 towards agrarian capitalism in Mallorca (1659-1800)

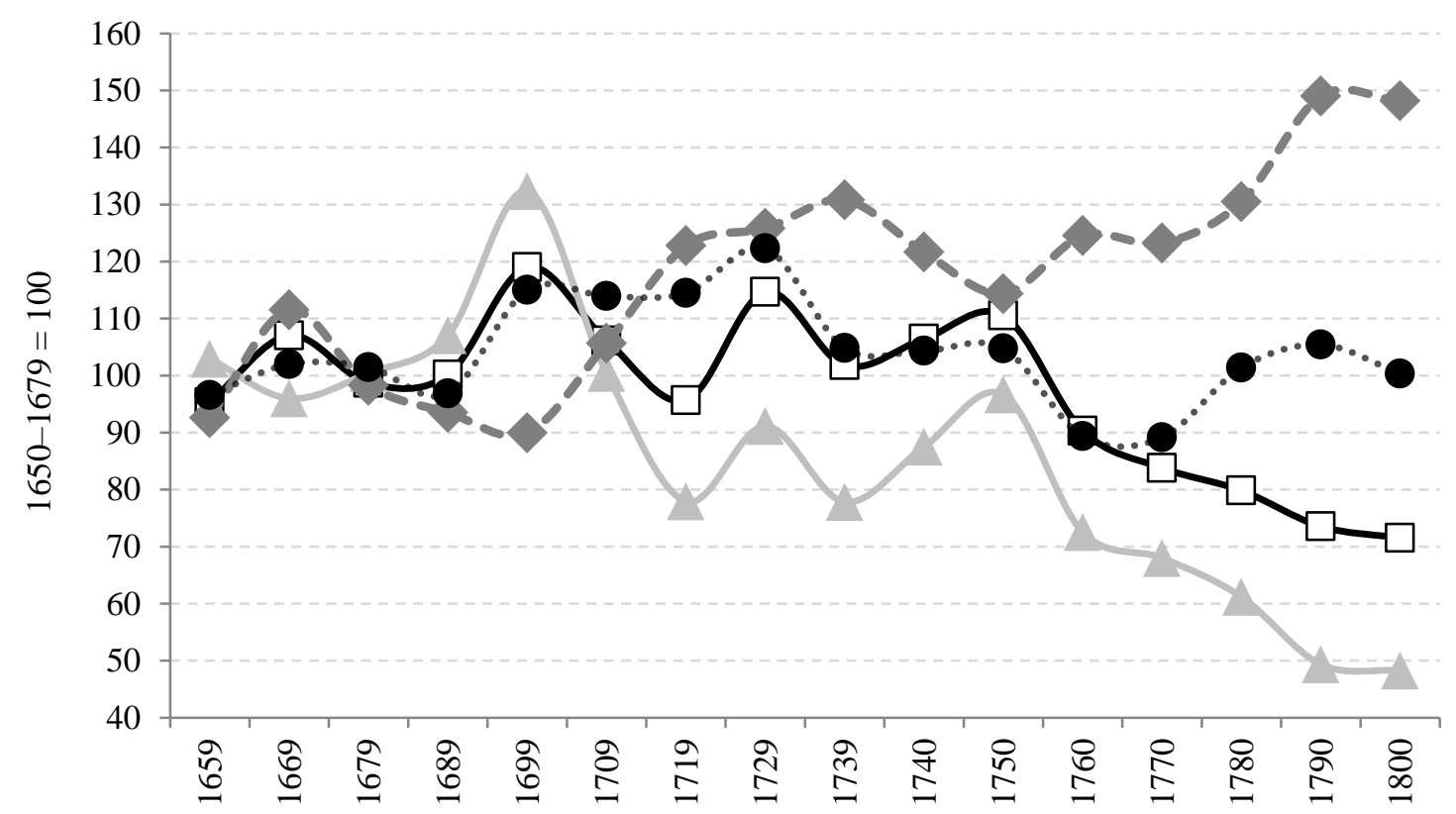

$\neg \square$ Real land rent in wheat terms

- Real agricultural wage in wheat terms

$-\diamond-$ Rental/wage ratio (Williamson Index)

3

..* Real wheat product per inhabitant

4 Sources: Our own, from Jover (1997, 647-658, 679-685).

5 
1 Figure 5 Changes in the composition of gross agricultural product along the

2 transition to agrarian capitalism in Mallorca (1574-1860)

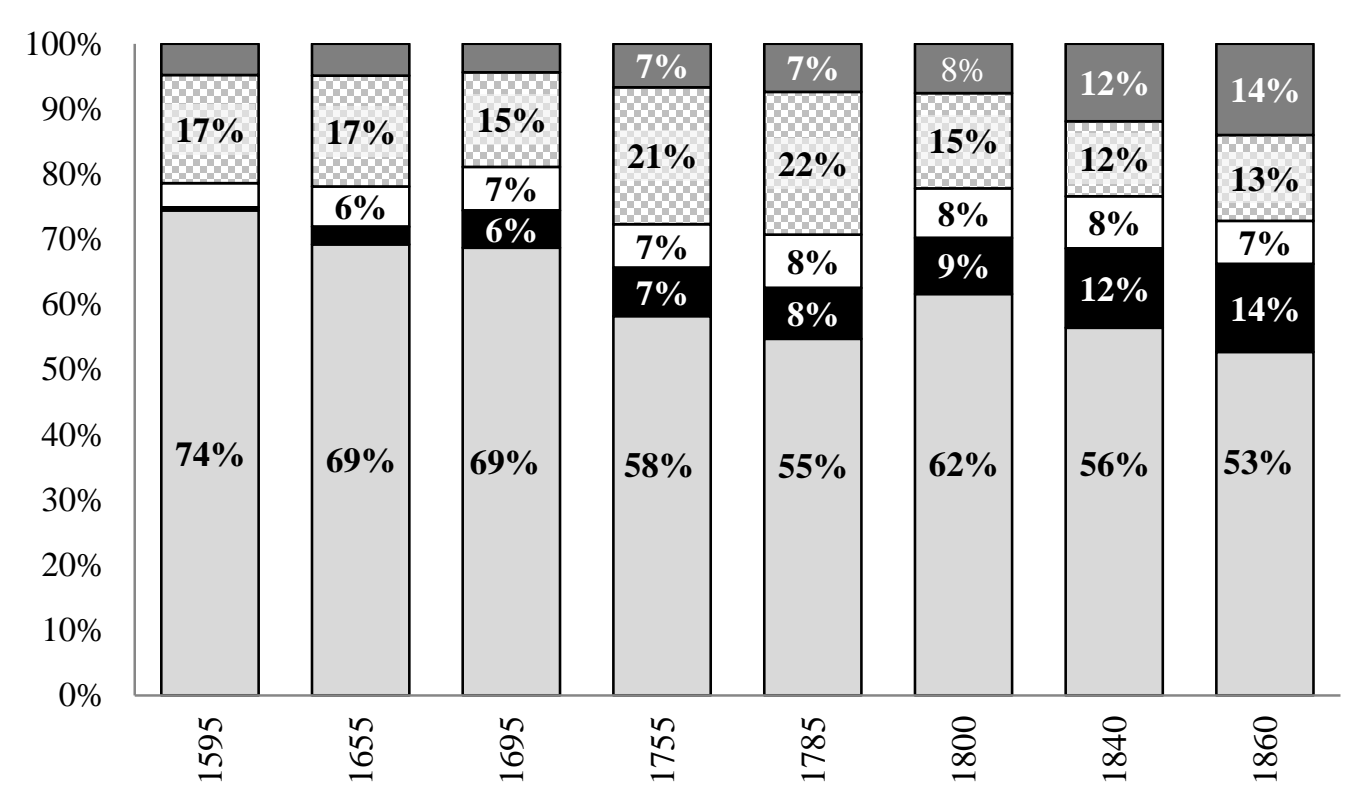

$\square$ cereals $\square$ legumes $\square$ wine $\quad \square$ olive oil $\square$ almonds, figs, carobs

4 Sources: Our own, from Jover and Manera $(2009,495)$.

5 
1 Figure 6 Population, agricultural product and productivity during the transition to

2 agrarian capitalism in Mallorca (1595-1860)

3

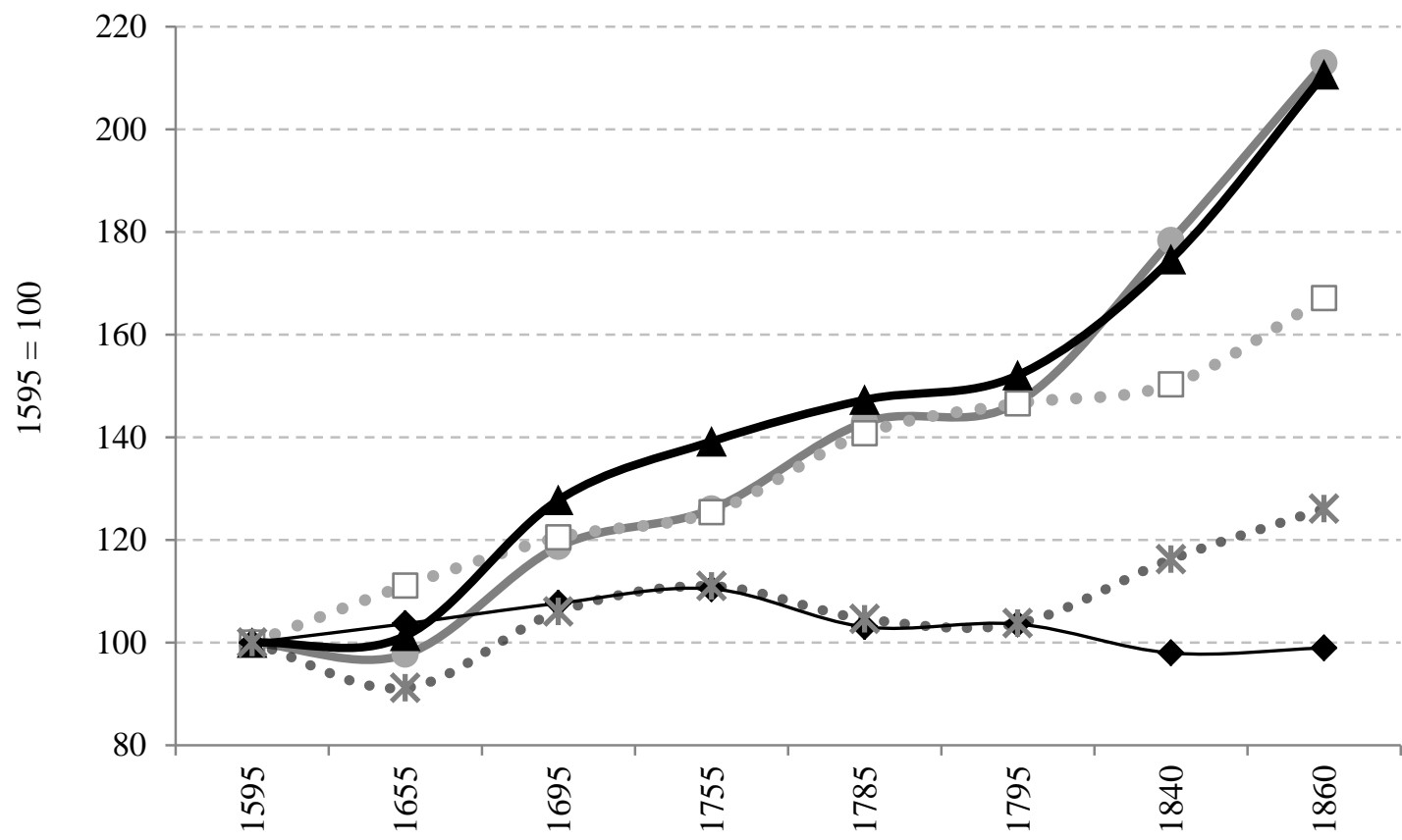

- A. Inhabitants

$\cdot \square \cdot$ B. Agricultural population

$\longrightarrow$ C. Agricultural product at constant prices of 1835

$\multimap$ D. Agricultural product per inhabitant (C/A)

•*••E. Agricultural product per agricultural active $(\mathrm{C} / \mathrm{B})$

4

5 Sources: Our own, from Jover and Manera $(2009,480)$.

6 
1 Figure 7 Tithes and tithe burdens per inhabitant along the transition to agrarian

2 capitalism in Mallorca $(1574-1583=100)$

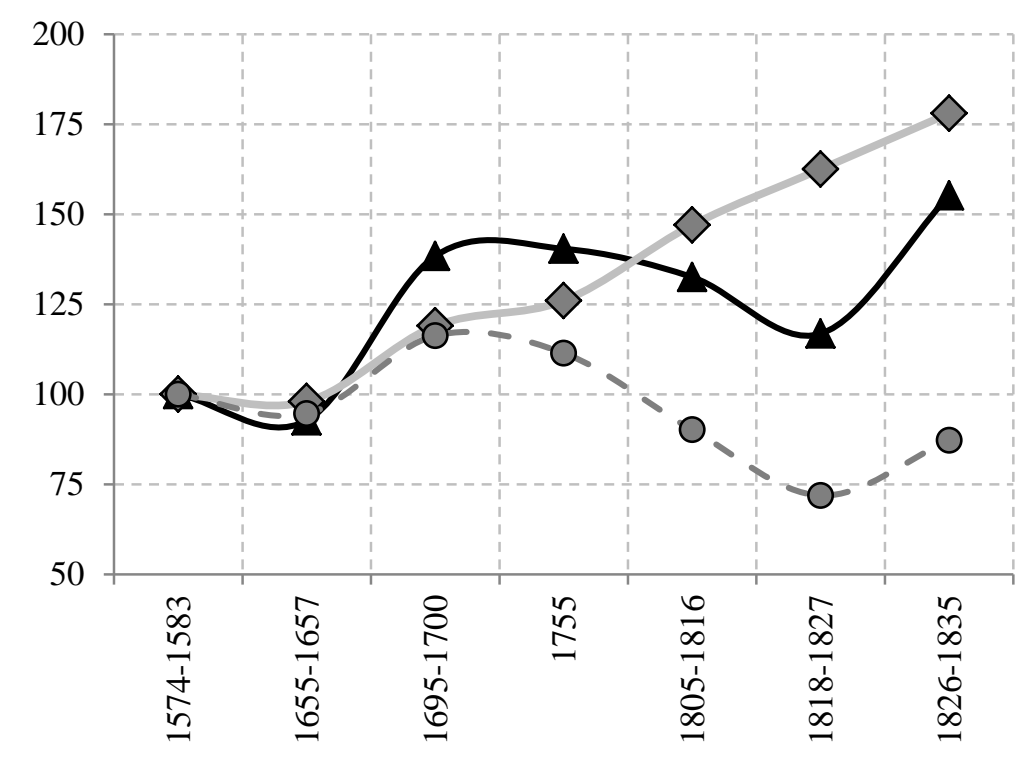

$\longrightarrow$ Total tithes at constant prices $\diamond$ population

3

$-0 \cdot$ total tithes per inhabitant

$4 \quad$ Sources: Our own, from Jover (1997, 278-282).

5 
1 Figure 8 Gini inequality indices of land ownership distribution according to the

2 cadastres compiled in 1818 and 1860 in Mallorca

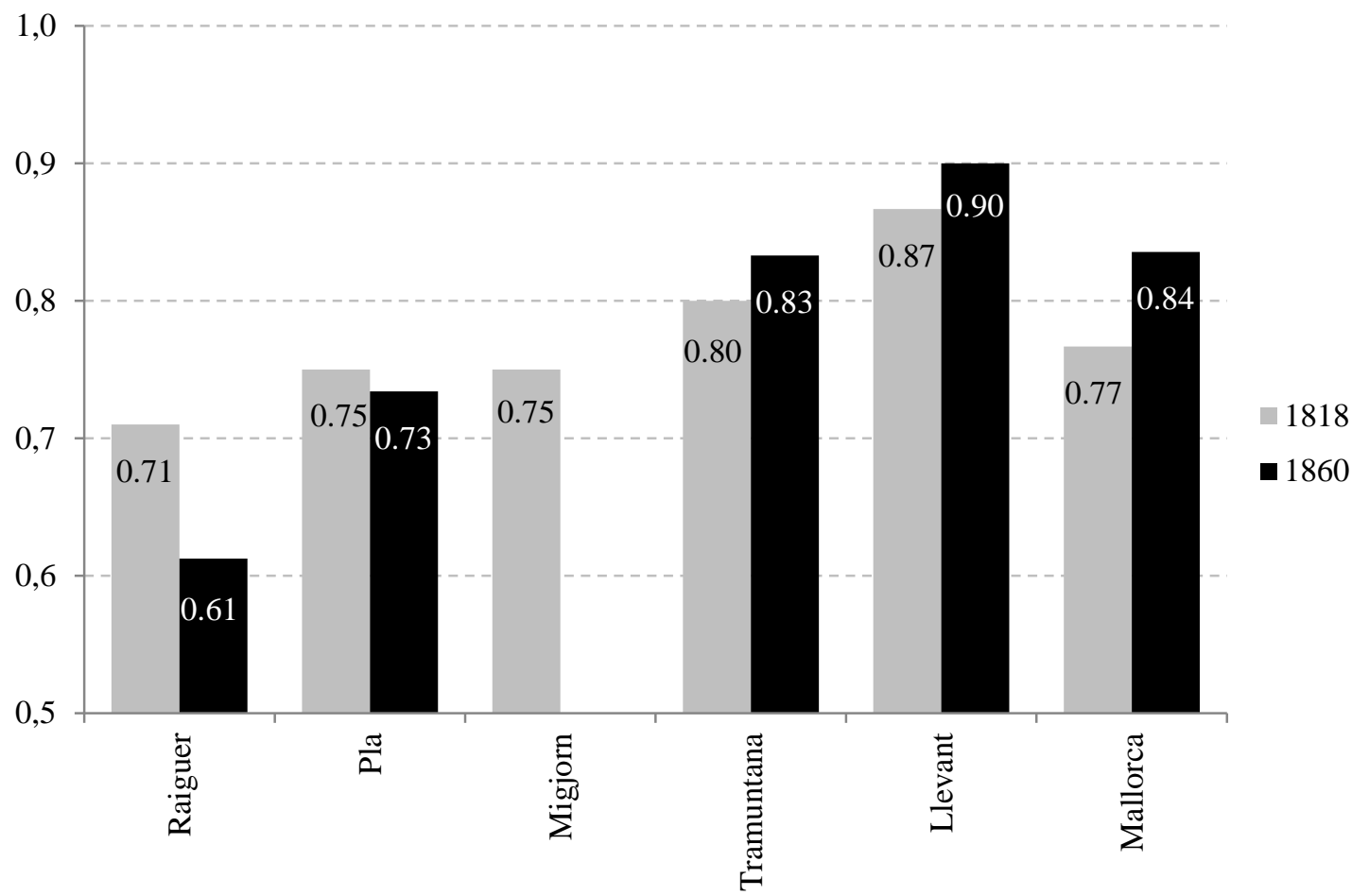

3

4 Sources: Our own, from Suau (1991, 116-117).

5

6

8

9

10 